\title{
PHYSIOLOGICAL AND MOLECULAR MECHANISMS UNDERLYING SALT STRESS TOLERANCE IN JOJOBA (SIMMONDSIA CHINENSIS)
}

\author{
Alghamdi, B. A..$^{*}$ - BAfEel, S. O. ${ }^{1}$-EDRIS, S. ${ }^{1,2,3}-$ AteF, A. ${ }^{1}$ - Al-MAtARY, M. ${ }^{1}$ - BAHIELDIN, A. ${ }^{1,2}$ \\ ${ }^{1}$ Department of Biological Sciences, Faculty of Science, King Abdulaziz University (KAU), \\ Jeddah, Saudi Arabia \\ (e-mail/ORCID: sbafil@kau.edu.sa/0000-0002-7912-1993-O. Bafeel; \\ sedris@aucegypt.edu/0000-0002-2810-3736-S.Edris; \\ ahmed_atefaig2@yahoo.com/0000-0001-7530-2060-A. Atef; \\ m.matri777@gmail.com/0000-0002-8815-0489-M. Al-Matary; \\ bahieldin55@gmail.com/0000-0002-6496-7881-A. Bahieldin) \\ ${ }^{2}$ Department of Genetics, Faculty of Agriculture, Ain Shams University, Cairo, Egypt \\ ${ }^{3}$ Princess Al-Jawhara Al-Brahim Centre of Excellence in Research of Hereditary Disorders \\ (PACER-HD), Faculty of Medicine, King Abdulaziz University (KAU), Jeddah, Saudi Arabia \\ *Corresponding author \\ e-mail: Budouralghamdi@gmail.com; ORCID: 0000-0003-4048-6052
}

(Received 28 ${ }^{\text {th }}$ Dec 2020; accepted $3^{\text {rd }}$ Mar 2021)

\begin{abstract}
The study aims to characterize the leaves of Jojoba (Simmondsia chinensis) under salt stress (50, 100 , and $200 \mathrm{mM} \mathrm{NaCl}$ ) at physiological and molecular levels. Physiological analysis included photosynthetic pigments of chlorophylls-a, and -b as well as carotenoids. $\mathrm{H}_{2} \mathrm{O}_{2}$ content as well as two antioxidant enzymes, namely catalase and ascorbate peroxidase, were also analyzed. Overall results of physiological parameters indicated their differential response due to the stress. Molecular analysis, done via RNA-Seq and mapping highly expressed transcripts to KEGG pathways, resulted in a large number of regulated genes under salt stress, of which, 13 genes in six pathways were further studied referring to the studied physiological parameters. These genes included $A L D O$ and TKT that promote both Calvin-Benson cycle and the production of erythrose4-phosphate that acts upstream nine genes towards better growth under stress conditions. Other genes included $H A O$ that mediates crosstalking of "carbon fixation in photosynthetic organisms" pathway and $A P X$ that participates in "Ascorbate and aldarate metabolism" pathway. Overall, the six pathways were proven to crosstalk under salt stress in Jojoba to provide salt stress tolerance. This information can help using this plant as a source of biodiesel in salinized soil or areas of water scarce.
\end{abstract}

Keywords: Chl, carotenoids, $\mathrm{H}_{2} \mathrm{O}_{2}, \mathrm{CAT}, \mathrm{APX}, \mathrm{ALDO}, \mathrm{TKT}, \mathrm{HAO}, \mathrm{RNA}-\mathrm{Seq}$, carbon fixation, tryptophan metabolism

\section{Introduction}

Salt stress imposes a challenge in agriculture sector worldwide (Liang et al., 2018). It results in the alteration of some metabolic pathways in plants underlying many physiological and biochemical processes (Bafeel et al., 2016). Next-generation sequencing (NGS) technologies coupled with computational tools allowed the study of transcriptomes of model and non-model organisms, especially those with no available genome sequencing data like Simmondsia chinensis (Link) Schneider (Martin and Wang, 2011; Garber et al., 2011; Jain, 2012; Nejat et al., 2018). The high-throughput RNA-Seq technology allows the study of the whole plant transcriptomes, the dynamics of gene expression and regulation towards the adaptability to soil salinity (Wang et al., 2009; Sailaja et al., 2014; Cao et al., 2018; Nejat et al., 2018). Understanding the 
physiological and molecular dynamics of salt stress responses will allow the development of genotypes with enhanced salt tolerance. Studying the plant response to such adverse conditions at the molecular and physiological levels will provide a new avenue towards the improvement of the agricultural productivity.

Jojoba (Simmondsia chinensis) is known for its important applications in biodiesel industry. It has several other applications due to medicinal properties including cosmetics and personal care formulations (Passerini and Lombardo, 2000; Al-Obaidi et al., 2017). However, due to the scarce of information of transcriptome of Jojoba, it is a challenge to detect genes and transcription factors that might confer salt stress tolerance. Transcriptomic analysis of plant responses to salt stress based on RNA-Seq has been performed in various species including Rhazya stricta (Hajrah et al., 2017), Arabidopsis (Kawa and Testerink, 2017), barley and rice (Ueda et al., 2006). As a result of abiotic and biotic stresses, production and accumulation of toxic reactive oxygen species (ROS) have been recorded by many researchers. These conditions result in oxidative stress and cause membrane leakage through increased lipid peroxidation (Bowler and Fluhr, 2000; Shah et al., 2001; Mittler, 2002; Panda and Khan, 2004; Wu et al., 2014). ROS also affects other important macromolecules including proteins, nucleic acids, photosynthetic pigments and lipids (Mittler, 2002; Wu et al., 2014; Hend et al., 2015). Antioxidants include both enzymatic (Superoxide dismutase (SOD), Catalase (CAT), Ascorbate peroxidase (APX), etc.) and nonenzymatic components that can reduce the chance of facing oxidative stress conditions by mediate scavenging of ROS (Mittler, 2002; Wu et al., 2014; Hend et al., 2015; Abd-Allah et al., 2015).

The present study aims at detecting transcriptome of Jojoba (Simmondsia chinensis (Link) Schneider) under salt stress in order to get better insights into some physiological mechanisms by which this plant species tolerates the stress. We will also try to get a better understanding of molecular processes complying to physiological data.

\section{Materials and methods}

\section{Plant material sampling and watering regime}

Experiment was conducted at the laboratories of the Department of Biological Sciences, King Abdulaziz University, Jeddah, Saudi Arabia. Jojoba seeds were grown in 10 pots in a growth chamber $(9 \mathrm{~cm}, 3$ seeds/pot) filled with soil mix (1 soil: 1 vermiculite) and watered with deionized double distilled water under the following growth conditions; e.g., $21 \pm 2{ }^{\circ} \mathrm{C}$ (day/night) under light intensity of $\sim 175$ umoles $\mathrm{m}^{-2}$ $\mathrm{s}^{-1}$ and a $16 \mathrm{~h}$-light/8 h-dark cycle. Experiment was designed as shown in Figure 1. Emerged plantlets were allowed first to grow for 19 days, then, they were morphologically screened for homozygosity and accordingly number of plantlets per pot was narrowed to one (Bahieldin et al., 2015). Then, pots were divided into two groups. The first group (five pots) was continued to be irrigated every five days with deionized double distilled water (control), while the other group was salt stressed (treatment). It was important to use distilled water to avoid impurities and indigenous microbes that can pose additional stress (biotic) to the plant. The plantlets were irrigated three times with intervals of five days. Salt stressed plantlets were first irrigated with $50 \mathrm{mM} \mathrm{NaCl}$, followed by 50 and $100 \mathrm{mM} \mathrm{NaCl}$ incremental increases, respectively, of salt stress as recommended by Munns (2002). The samples of the salt stressed plantlets were harvested after plantlets were exposed to 50, 100 and $200 \mathrm{mM} \mathrm{NaCl}$, respectively. 
Then, leaf samples of stressed and non-stressed plantlets were harvested the second day of irrigation at days 25, 30 and 35, respectively. Then, replicates of each group were divided for molecular and physiological analysis.

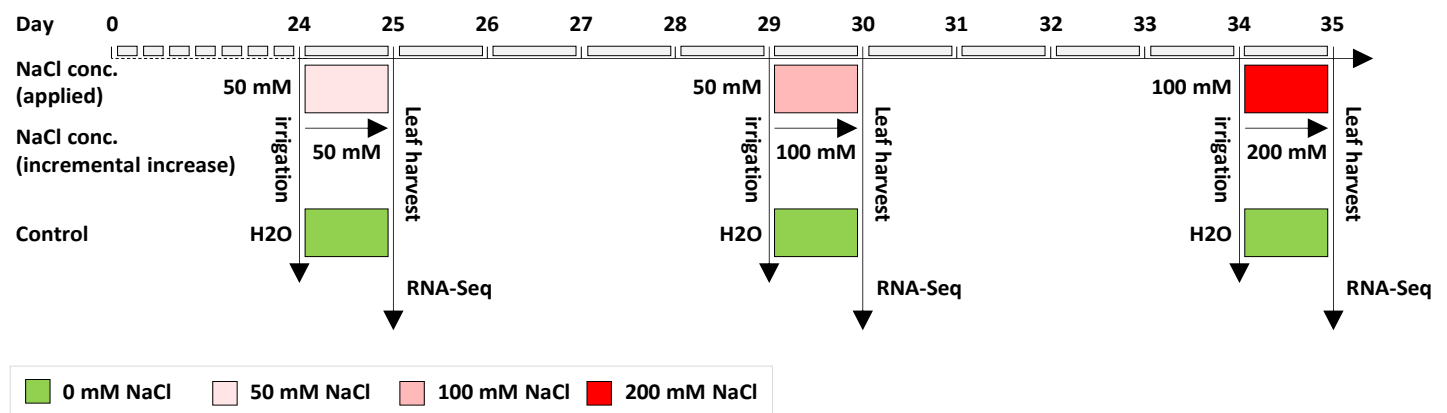

Figure 1. Schematic representation of the salt stress experiment conducted starting day 24 at three $\mathrm{NaCl}$ concentrations increased incrementally with five-day intervals $(50,100$, and $200 \mathrm{mM}$ ) in Jojoba plant. Leaf samples were harvested the second day of applying salt treatments (days 25, 30 and 35, respectively) for RNA-Seq analysis

\section{Physiological experiments}

\section{Determination of photosynthetic pigments}

Chlorophylls and carotenoids were measured using UV-VIS Spectroscopy according to Hiscox and Israelstam (1979) with some modifications (Su et al., 2010). $0.1 \mathrm{~g}$ of each fresh green leaf sample (three replicates) was placed in a test tube. Then, $5 \mathrm{ml}$ of ethanol $(95 \%)$ was added to each tube at $60{ }^{\circ} \mathrm{C}$. then (green solution) was homogenized with extraction and placed in a cuvette. The absorbance readings were determined spectrophotometry by Lambda $25 \mathrm{UV}-\mathrm{V}$ is spectrometer at wavelengths 663 , 644, and $452 \mathrm{~nm}$. Two $\mathrm{ml}$ of ethanol (95\%) was used as a blank. Chlorophylls and carotenoids concentrations were calculated using Equations 1, 2 and 3, respectively, according to Sumanta et al. (2014) as follows:

$$
\begin{aligned}
& \text { Chlorophyll-a }\left(\mathrm{Chl}_{\mathrm{a}}\right)=(13.36, \mathrm{~A} 664)-(5.19, \mathrm{~A} 649)=\mu \mathrm{g} / \mathrm{ml} \\
& \text { Chlorophyll-b }\left(\mathrm{Chl}_{\mathrm{b}}\right)=(27.43, \mathrm{~A} 649)-(8.12, \mathrm{~A} 664)=\mu \mathrm{g} / \mathrm{ml} \\
& \text { Carotenoid }(\mathrm{car})=\left[1000, \mathrm{~A} 470-\left(2.13 \mathrm{Chl}_{\mathrm{a}}-97.63 \mathrm{Chl}_{\mathrm{b}}\right)\right] / 209=\mu \mathrm{g} / \mathrm{ml}
\end{aligned}
$$

\section{Determination of hydrogen peroxide $\left(\mathrm{H}_{2} \mathrm{O}_{2}\right)$ content}

$\mathrm{H}_{2} \mathrm{O}_{2}$ content was measured according to Mukherjee and Choudhuri (1983) with some modification. $\mathrm{H}_{2} \mathrm{O}_{2}$ was extracted from homogenized leaf tissue $(0.5 \mathrm{~g})$ eluted in $5 \mathrm{~mL}$ of cold acetone. The extract was centrifuged at $6000 \mathrm{~g}$ for $25 \mathrm{~min}$, then, $5 \mathrm{ml}$ of sulfuric acid was added to $0.5 \mathrm{~g}$ of titanium dioxide, and solution was heated gently until fumes of sulfuric acid are evolved. After cooling, water was gradually added to reach $100 \mathrm{ml}$. Then, $3 \mathrm{ml}$ of supernatant was mixed with $1 \mathrm{ml}$ of titanium sulfate in $\mathrm{H}_{2} \mathrm{SO}_{4}$ and the mixture was centrifuged at $6000 \mathrm{~g}$ for $15 \mathrm{~min}$. The intensity of the yellow color of the supernatant was measured at $410 \mathrm{~nm}$ and $\mathrm{H}_{2} \mathrm{O}_{2}$ level was calculated using the extinction coefficient of $0.28 \mu \mathrm{mol}^{-1} \mathrm{~cm}^{-1}$. 


\section{Antioxidant enzymes activity}

\section{Antioxidant enzymes extraction}

The enzymes were extracted according to Cakmak and Marschner (1992) with some modifications. Leaves tissue $(0.5 \mathrm{~g})$ was grounded in liquid $\mathrm{N}_{2}$ to fine powder. Then, it was homogenized in $5 \mathrm{ml}$ of $100 \mathrm{mM}$ potassium phosphate buffer $(\mathrm{pH} 7.8)$ with $0.1 \mathrm{mM}$ ethylenediamine tetraacetic acid (EDTA) and $0.1 \mathrm{~g}$ polyvinyl pyrrolidone (PVP). The samples were then centrifuged at $18,000 \mathrm{rpm}$ for $10 \mathrm{~min}$ at $4{ }^{\circ} \mathrm{C}$, and the supernatants were collected to be used for enzymes activity assays.

Enzyme activities

(1) Catalase (CAT) (EC 1.11.1.6)

Determination of CAT activity was assayed according to the spectrophotometric modified method of Aebi (1984). The reaction medium contained $2600 \mathrm{ml}$ of $50 \mathrm{mM}$ potassium phosphate buffer ( $\mathrm{pH} 7$ ), and $100 \mu \mathrm{l}$ of the enzyme. The reaction initiated by adding $300 \mu \mathrm{l}$ of $10 \mathrm{mM} \mathrm{H} \mathrm{O}_{2}$. Three readings were scored, each after $3 \mathrm{~min}$. The absorbance was measured in spectrophotometer at $240 \mathrm{~nm}$. The catalase activity was calculated using the molar extinction coefficient $39.4 \mathrm{mmol} / \mathrm{cm}$. Enzyme activity was then calculated using Equation 4:

$$
\text { Enzyme activity }=\frac{\Delta \text { CAT } \times \text { extraction volume }}{\text { Fwt. } \mathrm{x} \text { analysis volume of enzyme extract }} \times \text { extinction coefficient }
$$

\section{(2) Ascorbate peroxidase (APX) (EC 1.11.1.11)}

Determination of Ascorbate peroxidase activity was assayed according to the spectrophotometric method of Nakano and Asada (1981). The activity was determined by the decreased absorption at $290 \mathrm{~nm}$ at 3 min-intervals due to ascorbate oxidation. Then, $200 \mu 1$ of enzyme extract was added in a cuvette and $2.5 \mathrm{ml}$ of $50 \mathrm{mM}$ potassium phosphate buffer ( $\mathrm{pH} 7$ ) was added. Then, $100 \mu \mathrm{l}$ of $5 \mathrm{mM} \mathrm{H}_{2} \mathrm{O}_{2}$ and $50 \mu 1$ of $0.1 \mathrm{mM}$ $\mathrm{Na}_{2}$-EDTA were added. Finally, $100 \mu \mathrm{l}$ of $0.5 \mathrm{mM}$ ascorbic acid was added to start the reaction. The absorbance was measured in spectrophotometer at $290 \mathrm{~nm}$. The ascorbate peroxidase activity was calculated using the molar extinction coefficient $2.8 / \mathrm{mmol} \times$ $\mathrm{cm}$. Enzyme activity was then calculated using Equation 5:

$$
\text { Enzyme activity }=\frac{\Delta \text { APX A } \times \text { extraction volume }}{\text { Fwt.x analysis volume of enzyme extract }} \times \text { extinction coefficient } \quad(\text { Eq.5) }
$$

\section{Statistical analysis}

Paired comparison of T-test was made between the control and treatment samples across each concentration. Threshold of $\mathrm{p}$-value $\leq .05$ was considered statistically significant.

\section{Molecular analysis}

Flash-frozen leaf materials from individual Jojoba plant samples were crushed into a fine powder in a microcentrifuge tube using a sterilized metal rod. Total RNA was extracted from three similar-sized $\left(10 \mathrm{~mm}^{2}\right)$ leaf discs per plant (approximately $50 \mathrm{mg}$ tissue) using Trizol (Invitrogen) and treated with RNase-free DNase (Promega Inc.). 
The yield and quality of RNA were determined using a Nanodrop-8000 spectrophotometer (Thermo Scientific, Wilmington, DE, USA). After RNAs were quantified, $30 \mu \mathrm{g}(400 \mathrm{ng} / \mu \mathrm{l})$ was used for RNA-Seq. To test for the presence of DNA contamination in RNA samples, the actin gene was amplified by PCR of the original RNA samples. RNA samples were then shipped to Beijing Genome Institute (BGI), Beijing, China for deep sequencing. Next-generation sequencing using illumina Miseq generated raw data in FASTQ format. Raw transcriptomic data of Jojoba were submitted to the NCBI for reviewing and receiving accession numbers.

Raw data was filtered and trimmed for low-quality score reads, then, adaptor and primer sequences were removed and reads less than $40 \mathrm{bp}$ were removed using Trimmomatic v0.30 (Bolger et al., 2014). Sequencing data with Phred quality score $Q \geq 20$ was further used in assembly. Expected read counts were used as input to differential expression analysis by EdgeR package (version 3.0.0, Robinson et al., 2010). Analysis of the RNA-Seq datasets indicated the recovery of $>5$ million reads per sample. De novo assembly was done for the different samples using the Trinity RNA-Seq Assembly package (r2013-02-25) with optimized parameters and K-mer size set to 25. CLC Genomics workbench (CLC Bio, Boston, MA 02108 USA) was used to validate the assembled transcript contigs by mapping high-quality reads back to the assembled transcript contigs. To identify the coding DNA sequences (CDS) from assembled transcript contigs, an online tool ORF-Predictor (Min et al., 2005) (http://proteomics.ysu.edu/tools/OrfPredictor.html) with the default parameters was used. Then, differential expression and cluster analysis were done by EdgeR (version 3.0.0). Blastx was performed (with an E-value cut off of $1 \mathrm{e}^{-5}$ ) and fold change values of differentially expressed transcripts were measured against the actin used as the housekeeping gene.

Significant Pearson correlation was determined during permutation analysis. The generated clusters were analyzed for GO terms using Blast2GO (http://www.blast2go.org/). GO terms for all the BLASTX functionally annotated CDS was retrieved using GO mapping. CDS were categorized by WEGO analysis which involved sketching a WEGO plot based on GO hits. To retrieve GO terms for annotated CDS, the GO mapping used defined criteria. This included use of (i) BLASTX result accession IDs to retrieve gene names or symbols, (ii) UniProt IDs, and (iii) direct search in the dbxref table of the GO database. Gene names or symbols thus identified were then searched against the species-specific entries of the gene-product tables in GO database. To retrieve UniProt IDs, Protein Information Resource (PIR) was used. PIR includes protein sequence database (PSD), UniProt, SwissProt, TrEMBL, RefSeq, GenPept, and PDB databases. Using GO analysis, all the annotated nodes comprising GO functional groups were specified.

All predicted CDS were annotated against protein database in order to assign putative function of the transcriptome after translation into protein. The regulated genes under salt stress $(200 \mathrm{mM} \mathrm{NaCl})$ were mapped across its corresponding control to reference canonical pathways in the Kyoto Encyclopedia of Genes and Genomes (KEGG) (http://www.genome.ad.jp/kegg/).

\section{Results}

Leaf samples were harvested 1, 6 and 11 days after plantlets initially exposed to salt stress. Due to the incremental increase of salt stress pressure, the concentrations of salt stress at the latter time points were 50, 100 and $200 \mathrm{mM} \mathrm{NaCl}$. This took place when 
plantlets were 25-, 30- and 35-days old, respectively, after seeds were put for germination. The reason for the incremental increase of salt stress is to allow plants to gradually adapt to salt stress.

\section{Physiological parameters related to salt stress}

\section{Plant pigments}

According to the results in Figure $2 a$, chlorophyll-a ( $\left.\mathrm{Chl}_{\mathrm{a}}\right)$ slightly inhibited in salt (50 and $100 \mathrm{mM} \mathrm{NaCl}$ ) treated plants compared to their respective control plants at days 25 and 30, respectively, while slightly increased in salt treated plants compared to its respective control plant at day 35 with salt concentration of $200 \mathrm{mM} \mathrm{NaCl}$. Table Al (see Appendix) indicates that the mean $\mathrm{Chl}_{\mathrm{a}}$ contents in control and salt $(50 \mathrm{mM} \mathrm{NaCl})$ treated plants at day 25 were 2.56 and $2.42 \mathrm{mg} / \mathrm{g} \mathrm{FW}$, respectively, while Chl contents in control and salt $(100 \mathrm{mM} \mathrm{NaCl})$ treated plants at day 30 were 1.95 and $1.70 \mathrm{mg} / \mathrm{g}$ $\mathrm{FW}$, respectively, and decreased to $1.36 \mathrm{mg} / \mathrm{g} \mathrm{FW}$ at day 35 in control plants, while not changed (e.g., $1.71 \mathrm{mg} / \mathrm{g} \mathrm{FW})$ in salt $(200 \mathrm{mM} \mathrm{NaCl})$ treated plants.

None of the three time points showed significant differences between means of control and respective salt treated plants (Table Al). Figure $2 b$ illustrates slight increase of chlorophyll-b $\left(\mathrm{Chl}_{\mathrm{b}}\right)$ content in salt $(100 \mathrm{mM} \mathrm{NaCl})$ treated plants at day 30 compared to their respective control plants, while significant decrease at day 35 in salt $(200 \mathrm{mM} \mathrm{NaCl})$ treated plants compared to its respective control plants. Table Al indicates that the mean Chlb contents at day 25 in control and salt $(50 \mathrm{mM} \mathrm{NaCl})$ treated plants were 3.14 and $3.04 \mathrm{mg} / \mathrm{g} \mathrm{FW}$, respectively, while Chlb contents at day 30 in control and salt $(100 \mathrm{mM}$ $\mathrm{NaCl}$ ) treated plants increased to 5.05 and $5.85 \mathrm{mg} / \mathrm{g} \mathrm{FW}$, respectively, and slightly changed to 5.48 and $4.76 \mathrm{mg} / \mathrm{g} \mathrm{FW}$, respectively, at day 35 in control and salt $(200 \mathrm{mM}$ $\mathrm{NaCl}$ ) treated plants. Figure $2 c$ showed no significant difference in the carotenoid content at day 25 between salt $(50 \mathrm{mM} \mathrm{NaCl})$ treated plants compared to its respective control plant, while significant increase in the carotenoid content in salt $(100 \mathrm{mM} \mathrm{NaCl})$ treated plants at day 30 compared to the control plants, and a significant decrease in salt $(200 \mathrm{mM}$ $\mathrm{NaCl}$ ) treated plants at day 35 compared to the control plants. Table Al indicates that the mean carotenoid contents in control and salt $(50 \mathrm{mM} \mathrm{NaCl})$ treated plants at day 25 were 8.67 and $7.96 \mathrm{mg} / \mathrm{g} \mathrm{FW}$, respectively, while carotenoid contents were increased to 12.92 and $14.78 \mathrm{mg} / \mathrm{g} \mathrm{FW}$ at day 30 in control and salt $(100 \mathrm{mM} \mathrm{NaCl})$ treated plants, respectively, and almost not changed (e.g., $13.57 \mathrm{mg} / \mathrm{g} \mathrm{FW}$ ) at day 35 in control plants, while reduced to 10.18 in salt $(200 \mathrm{mM} \mathrm{NaCl})$ treated plants. Overall, there are no significant differences between control and salt treated plants at $50 \mathrm{mM} \mathrm{NaCl}$ in terms of the three types of pigments (Fig. 2 and Table Al).

\section{Hydrogen peroxide $\left(\mathrm{H}_{2} \mathrm{O}_{2}\right)$}

The results in Figure 3 indicates that $\mathrm{H}_{2} \mathrm{O}_{2}$ concentration $\left(\mu \mathrm{mol}^{-1} \mathrm{~cm}^{-1}\right)$ significantly decreased at 50 and $100 \mathrm{mM} \mathrm{NaCl}$, while significantly increased at the salt concentration of $200 \mathrm{mM} \mathrm{NaCl}$. Table A2 indicates that the mean $\mathrm{H}_{2} \mathrm{O}_{2}$ contents in control and salt $(50 \mathrm{mM} \mathrm{NaCl})$ treated plants at day 25 were 13.12 and $9.32 \mu \mathrm{mol}^{-1} \mathrm{~cm}^{-}$ ${ }^{1}$, respectively, while contents were 11.71 and $8.99 \mu \mathrm{mol}^{-1} \mathrm{~cm}^{-1}$, respectively, at day 30 in control and salt $(100 \mathrm{mM} \mathrm{NaCl})$ treated plants and became 12.34 and $15.22 \mu \mathrm{mol}^{-1}$ $\mathrm{cm}^{-1}$, respectively, at day 35 in control and salt $(200 \mathrm{mM} \mathrm{NaCl})$ treated plants. The overall results indicate that $\mathrm{H}_{2} \mathrm{O}_{2}$ is highly sensitive to salt stress as its concentration significantly changed at different levels of salt stress. 


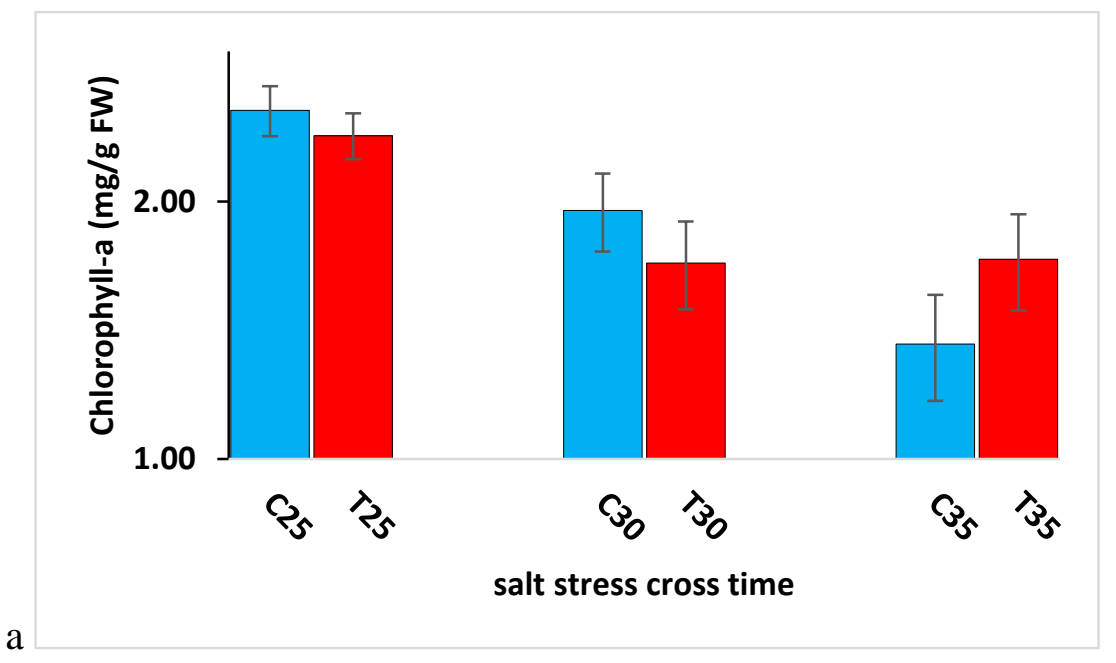

a

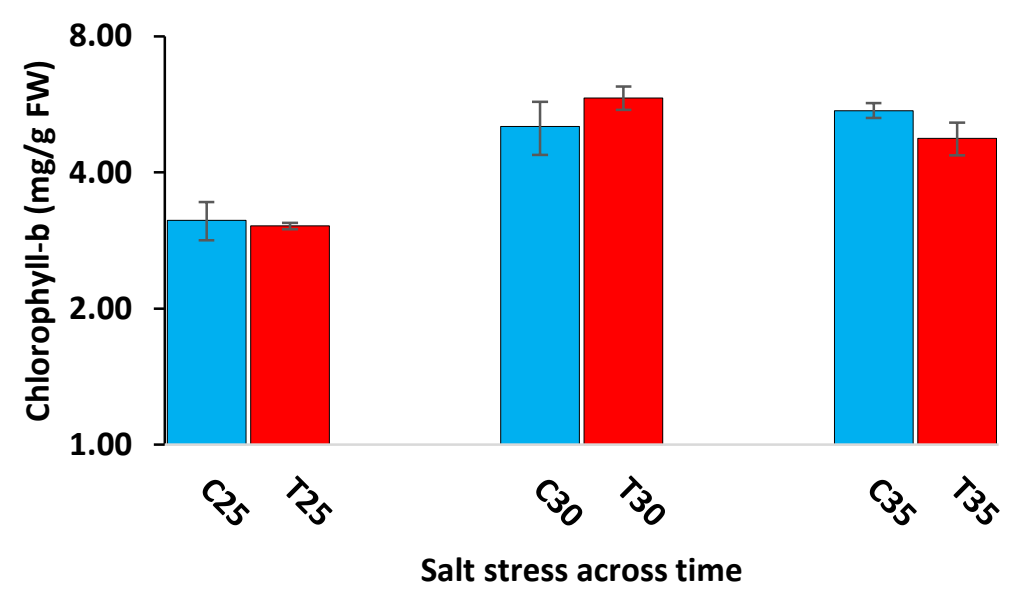

b

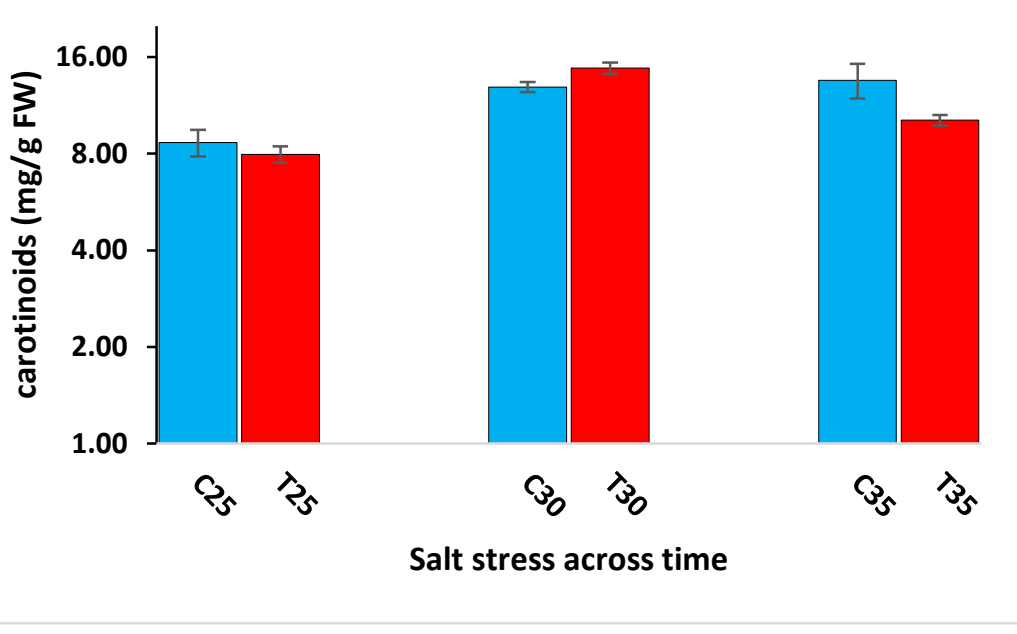

Figure 2. Means of chlorophyll-a (a), chlorophyll-b (b) and carotenoids $(c)(\mathrm{mg} / \mathrm{g} F W)$ in leaves of non-salinized (control) and salinized (treatment) Jojoba plants at three $\mathrm{NaCl}$ concentrations (50, 100, and $200 \mathrm{mM}$ ) increased incrementally with five-day intervals and harvested at the second day (days 25, 30 and 35, respectively). Means were calculated for three replicates. Vertical bars indicate \pm SE. Statistical analysis was done with $P$ value of $<0.05$.

$$
\text { * = significant }
$$




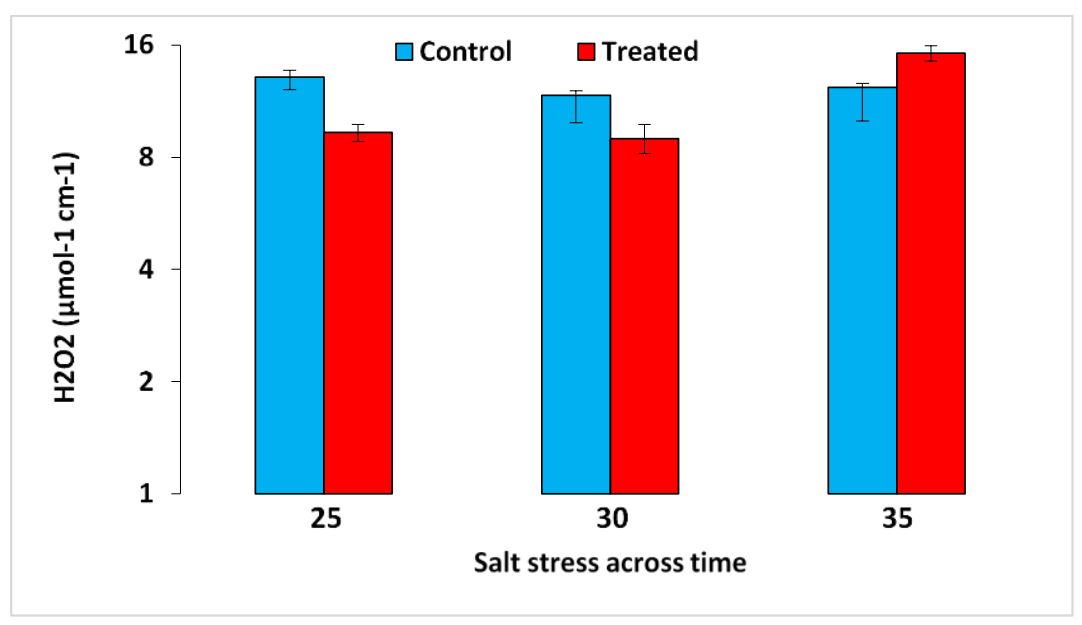

Figure 3. Means of hydrogen peroxide $\left(\mathrm{H}_{2} \mathrm{O}_{2}\right)$ concentration $\left(\mu \mathrm{mol} \mathrm{l}^{-1} \mathrm{~cm}^{-1}\right)$ in leaves of nonsalinized (control) and salinized (treatment) Jojoba plants at three $\mathrm{NaCl}$ concentrations (50, 100 , and $200 \mathrm{mM}$ ) increased incrementally with five-day intervals and harvested at the second day (days 25, 30 and 35, respectively). Means were calculated for three replicates. Vertical bars indicate \pm SE. Statistical analysis was done with $P$ value of $<0.05$. ** $=$ very significant, $* * *=$ highly significant

\section{Enzyme activities}

The results in Figure 4 for catalase (CAT) activity (U/g FW) in plant leaves indicated significant increase at 50 and $100 \mathrm{mM} \mathrm{NaCl}$, while non-significantly increased at $200 \mathrm{mM} \mathrm{NaCl}$. Table A2 indicates that the mean CAT activities in control and salt $(50 \mathrm{mM} \mathrm{NaCl})$ treated plants at day 25 were 13.11 and $27.16 \mathrm{U} / \mathrm{g} \mathrm{FW}$, respectively, while CAT activities were 41.88 and $168.53 \mathrm{U} / \mathrm{g} \mathrm{FW}$, respectively, at day 30 in control and salt $(100 \mathrm{mM} \mathrm{NaCl})$ treated plants and reduced to 35.35 and $45.93 \mathrm{U} / \mathrm{g} \mathrm{FW}$, respectively, at day 35 in control and salt $(200 \mathrm{mM} \mathrm{NaCl})$ treated plants. Aascorbate peroxidase (APX) activity (U/g FW), shown in Figure 5, in plant leaves significantly increased at $100 \mathrm{mM}$ $\mathrm{NaCl}$, while non-significantly increased at 50 and $200 \mathrm{mM} \mathrm{NaCl}$. Table A2 indicates that the mean APX activities in control and salt $(50 \mathrm{mM} \mathrm{NaCl})$ treated plants at day 25 were 4.58 and $5.98 \mathrm{U} / \mathrm{g} \mathrm{FW}$, respectively, while APX activities were 7.06 and $11.23 \mathrm{U} / \mathrm{g} \mathrm{FW}$, respectively, at day 30 in control and salt $(100 \mathrm{mM} \mathrm{NaCl})$ treated plants and became 14.84 and $15.63 \mathrm{U} / \mathrm{g} \mathrm{FW}$, respectively, at day 35 in control and salt $(200 \mathrm{mM} \mathrm{NaCl})$ treated plants. The overall results indicate that showed the same pattern of activity under salt stress as its level significantly increased at $100 \mathrm{mM} \mathrm{NaCl}$ salt stress, while no significant increases were observed at 50 and $200 \mathrm{mM} \mathrm{NaCl}$. These results indicate that these two enzymes have no prolonged effect under salt stress.

\section{Molecular genetic parameters related to salt stress}

Assembly of transcripts resulted in a large number of genes regulated under the pressure of incremental increases of salt stress (Table A3). These genes were mapped to reference canonical pathways in the Kyoto Encyclopedia of Genes and Genomes (KEGG) (http://www.genome.ad.jp/kegg/). We have used the term enrichment referring to the increase of gene-encoded enzymes or metabolites in salt-stressed (200 $\mathrm{mM} \mathrm{NaCl}$ ) plants compared to the non-stressed. Enriched metabolite indicates that encoding gene is highly expressed under salt stress. The primary gene selection 
criterion was based on the high level ( $\geq 5$ FC) of expression. In the present study, we focused on highly expressed genes in order to detect some molecular mechanisms used by Jojoba to respond positively to salt stress and probably confer tolerance. The secondary selection criterion involved genes complementing the detected physiological responses to salt stress. Expression levels of three of these genes ( $A L D O, T K T$ and $H A O$ ) were validated via qPCR and results complemented those of RNA-Seq (data provided upon request).

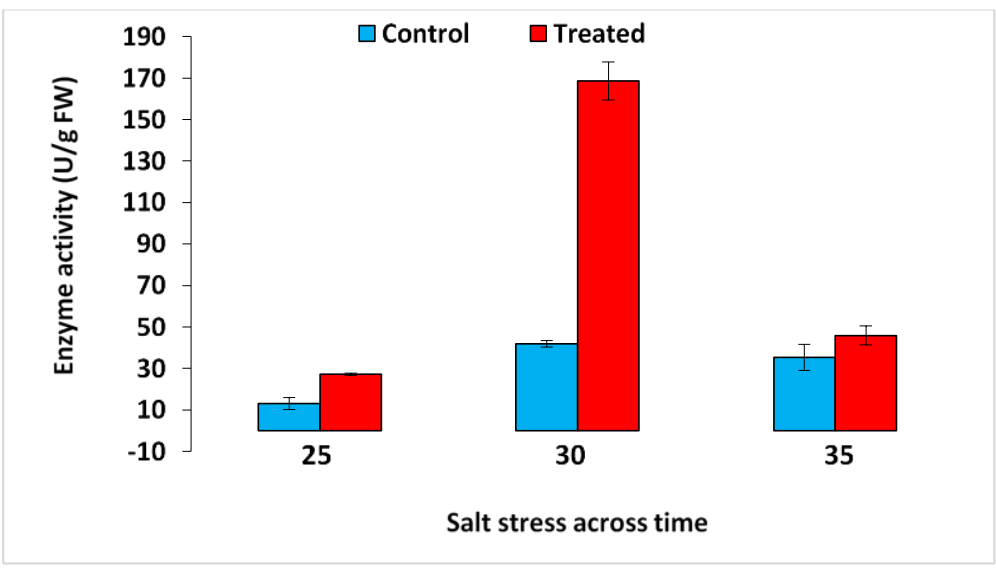

Figure 4. Means of catalase (CAT) activity $(U / g F W)$ in leaves of non-salinized (control) and salinized (treatment) Jojoba plants at three $\mathrm{NaCl}$ concentrations (50, 100, and $200 \mathrm{mM}$ ) increased incrementally with five-day intervals and harvested at the second day (days 25, 30 and 35, respectively). Means were calculated for three replicates. Vertical bars indicate $\pm S E$. Statistical analysis was done with $P$ value of $<0.05$. $* * *=$ highly significant

\section{KEGG analysis}

Referring to the physiological parameters involved in the differential response to salt stress in Jojoba plant leaves, a number of 13 enzyme-coding genes in addition to five protein-coding genes were studied (Table 1). Among these pathways, "carbon fixation in photosynthetic organisms", "ascorbate and aldarate metabolism" and "glyoxylate and dicarboxylate" are major players (Figs. Al-A3, respectively). The "carbon fixation in photosynthetic organisms" pathway is the gate towards the opening of other downstream cross-talking pathways (Figs. A4-A6). The latter pathways are "phenylalanine, tyrosine and tryptophan biosynthesis" (Fig. A4), "tryptophan metabolism" (Fig. A5) and "plant hormone signal transduction" (Fig. A6). These pathways act in promoting plant's ability to stand harsh environmental conditions.

\section{Carbon fixation in photosynthetic organisms}

Physiological analysis in the present study indicated the involvement of the two chlorophyll $\left(\mathrm{Chl}_{\mathrm{a}}\right.$ and $\left.\mathrm{Chl}_{\mathrm{b}}\right)$ pigments as well as carotenoid pigment in the plant response to salt stress. These pigments are the main contributors to the process of carbon fixation during photosynthesis. Molecular analysis indicated the participation of two important upregulated genes in the "carbon fixation in photosynthetic organisms" pathway (Fig. Al). These two genes are $A L D O$ that encodes fructose-bisphosphate aldolase (EC: 4.1.2.13) and the other gene is $T K T$ that encodes transketolase (EC: 2.2.1.1) (Table 1). The two gene, e.g., $A L D O$ and $T K T$, was upregulated under salt stress 
(50, 100 and $200 \mathrm{mM} \mathrm{NaCl}$ ) (Fig. 6). ALDO gene participates in 11 pathways, while TKT gene participates in eight pathways (Table 1). In the "carbon fixation in photosynthetic organisms" pathway, fructose-bisphosphate aldolase is enriched under salt stress in Jojoba to participate in the conversion of glyceraldehyde-3-phosphate via two routes of the pathway (Fig. Al). The first route refers to the conversion of glyceraldehyde-3-phosphate to fructose-1,6-biphosphate, while the second route is a bypass through triosephosphate isomerase for the conversion of glyceraldehyde-3phosphate to sedoheptulose-1,7-biphosphate. These two routes promote the occurrence of Calvin-Benson cycle, hence carbon fixation, which are important processes in providing energy required under salt stress.

Enrichment of the other enzyme transketolase makes the cell favors the first route in which glyceraldehyde-3-phosphate is converted via the three enzymes fructosebisphosphate aldolase, fructose-1,6-bisphosphatase I and transketolase to erythrose-4phosphate. This first route also indicates that glyceraldehyde-3-phosphate can directly be converted by transketolase to erythrose-4-phosphate as a bypass.

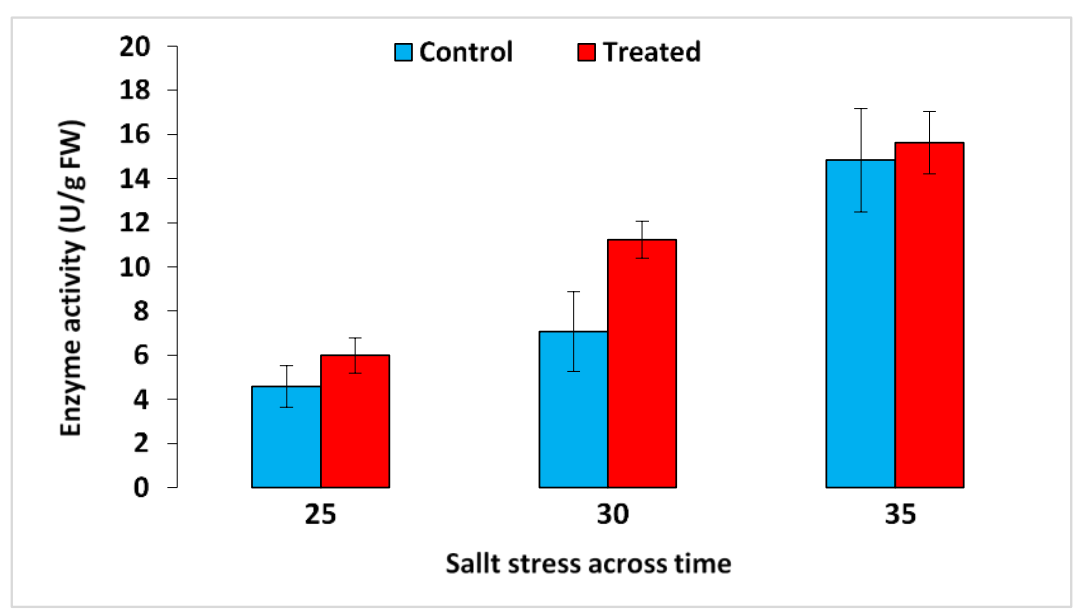

Figure 5. Means of ascorbate peroxidase (APX) activity $(U / g F W)$ in leaves of non-salinized (control) and salinized (treatment) Jojoba plants at three $\mathrm{NaCl}$ concentrations (50, 100, and $200 \mathrm{mM}$ ) increased incrementally with five-day intervals and harvested at the second day (days 25, 30 and 35, respectively). Means were calculated for three replicates. Vertical bars indicate \pm SE. Statistical analysis was done with $P$ value of $<0.05$. * significant

Table 1. Enriched enzymes and pathways under salt stress in leaves of Jojoba plants

\begin{tabular}{c|c|c}
\hline Accession no. & Enzyme & Pathway \\
\hline & & Biosynthesis of amino acids \\
& & Biosynthesis of secondary metabolites \\
& Carbon fixation in photosynthetic \\
EC: 4.1 .2 .13 & organisms \\
& Fructose-bisphosphate aldolase & Carbon metabolism \\
& & Fructose and mannose metabolism \\
& Glycolysis/Gluconeogenesis \\
& HIF-1 signaling \\
& & Metabolic pathways \\
& Methane Metabolism \\
& Microbial metabolism in diverse environments \\
& Pentose phosphate \\
\hline
\end{tabular}




\begin{tabular}{|c|c|c|}
\hline EC: 2.2.1.1 & Transketolase & $\begin{array}{c}\text { Biosynthesis of amino acids } \\
\text { Biosynthesis of ansamycins } \\
\text { Biosynthesis of secondary metabolites } \\
\text { Carbon fixation in photosynthetic } \\
\text { organisms } \\
\text { Carbon metabolism } \\
\text { Metabolic pathways } \\
\text { Microbial metabolism in diverse environments } \\
\text { Pentose phosphate }\end{array}$ \\
\hline EC: E2.5.1.54 & $\begin{array}{l}\text { 3-deoxy-7-phosphoheptulonate } \\
\text { synthase }\end{array}$ & $\begin{array}{c}\text { Phenylalanine, tyrosine and tryptophan } \\
\text { biosynthesis } \\
\text { Metabolic pathways } \\
\text { Biosynthesis of secondary metabolites } \\
\text { Biosynthesis of amino acids } \\
\text { Quorum sensing }\end{array}$ \\
\hline $\begin{array}{l}\text { EC: } 4.2 .1 .10 \\
\text { EC: } 2.4 .2 .18 \\
\text { EC: } 4.1 .1 .48\end{array}$ & $\begin{array}{c}\text { 3-dehydroquinate dehydratase I } \\
\text { Anthranilate phosphoribosyl } \\
\text { transferase } \\
\text { Indole-3-glycerol phosphate synthase }\end{array}$ & $\begin{array}{c}\text { Phenylalanine, tyrosine and tryptophan } \\
\text { biosynthesis } \\
\text { Metabolic pathways } \\
\text { Biosynthesis of secondary metabolites }\end{array}$ \\
\hline EC: 4.1.3.27 & Anthranilate synthase & $\begin{array}{c}\text { Phenylalanine, tyrosine and tryptophan } \\
\text { biosynthesis } \\
\text { Phenazine biosynthesis } \\
\text { Metabolic pathways } \\
\text { Biosynthesis of secondary metabolites }\end{array}$ \\
\hline EC: 4.2.1.20 & Tryptophan synthase & $\begin{array}{c}\text { Glycine, serine and threonine metabolism } \\
\text { Phenylalanine, tyrosine and tryptophan } \\
\text { biosynthesis } \\
\text { Metabolic pathways } \\
\text { Biosynthesis of secondary metabolites }\end{array}$ \\
\hline $\begin{aligned} \text { EC: } 2.6 .1 .99 \\
\text { EC: } 1.14 .13 .168 \\
\end{aligned}$ & $\begin{array}{l}\text { Tryptophan pyruvate aminotransferase } \\
\text { Indole-3-pyruvate monooxygenase }\end{array}$ & $\begin{array}{c}\text { Tryptophan metabolism } \\
\text { Metabolic pathways }\end{array}$ \\
\hline EC:3.5.1.4 & Amidase & $\begin{array}{c}\text { Arginine and proline metabolism } \\
\text { Phenylalanine metabolism } \\
\text { Tryptophan metabolism } \\
\text { Aminobenzoate degradation } \\
\text { Styrene degradation } \\
\text { Metabolic pathways } \\
\text { Microbial metabolism in diverse environments }\end{array}$ \\
\hline EC: 1.1 .3 .15 & (S)-2-hydroxy-acid oxidase & $\begin{array}{l}\text { Biosynthesis of secondary metabolites } \\
\text { Glyoxylate and dicarboxylate metabolism } \\
\text { Metabolic pathways } \\
\text { Microbial metabolism in diverse environments }\end{array}$ \\
\hline EC: 1.11 .1 .11 & L-ascorbate peroxidase & $\begin{array}{c}\text { Ascorbate and aldarate metabolism } \\
\text { Glutathione Metabolism } \\
\text { Metabolic pathways }\end{array}$ \\
\hline
\end{tabular}

Pathways discussed are shown in bold letters

\section{Downstream crosstalking pathways}

Erythrose-4-phosphate is an important metabolite in the occurrence of carbon fixation via fructose-bisphosphate aldolase and transketolase as previously indicated. In the present study, erythrose-4-phosphate acted as a rate limiting metabolite that wired another important cross-talking pathway namely "phenylalanine, tyrosine and tryptophan 
biosynthesis" towards the production of tryptophan (Fig. A4). This has taken place via the upregulation under salt stress of as much as six genes encoding 3-deoxy-7phosphoheptulonate synthase (EC: E2.5.1.54), 3-dehydroquinate dehydratase I (EC: 4.2.1.10), anthranilate synthase (EC: 4.1.3.27), anthranilate phosphoribosyl transferase (EC: 2.4.2.18), indole-3-glycerol phosphate synthase (EC: 4.1.1.48) and tryptophan synthase (EC: 4.2.1.20) (Fig. 7). Of which, the first enzyme (e.g., 3-deoxy-7phosphoheptulonate synthase) acts as the rate-limiting step of the pathway. Then, tryptophan is converted to the important auxin namely indole acetic acid (IAA) via two routes, each containing two steps in "tryptophan metabolism" pathway (Fig. A5). The first two-step route involves the upregulation of genes encoding tryptophan pyruvate aminotransferase (EC: 2.6.1.99) and indole-3-pyruvate monooxygenase (EC: 1.14.13.168). The second route involves the upregulation in the second step involving amidase (EC:3.5.1.4) (Fig. 8). IAA is known as a rate limiting metabolite in "plant hormone signal transduction" pathway towards the production of many other metabolites (e.g., AUX, TIR, ARF, GH3, SAUR, etc.) that promote cell enlargement and overall high plant growth, thus, confers stress tolerance. Several of the genes encoding these important metabolites were upregulated under salt stress (Figs. 9 and A6).

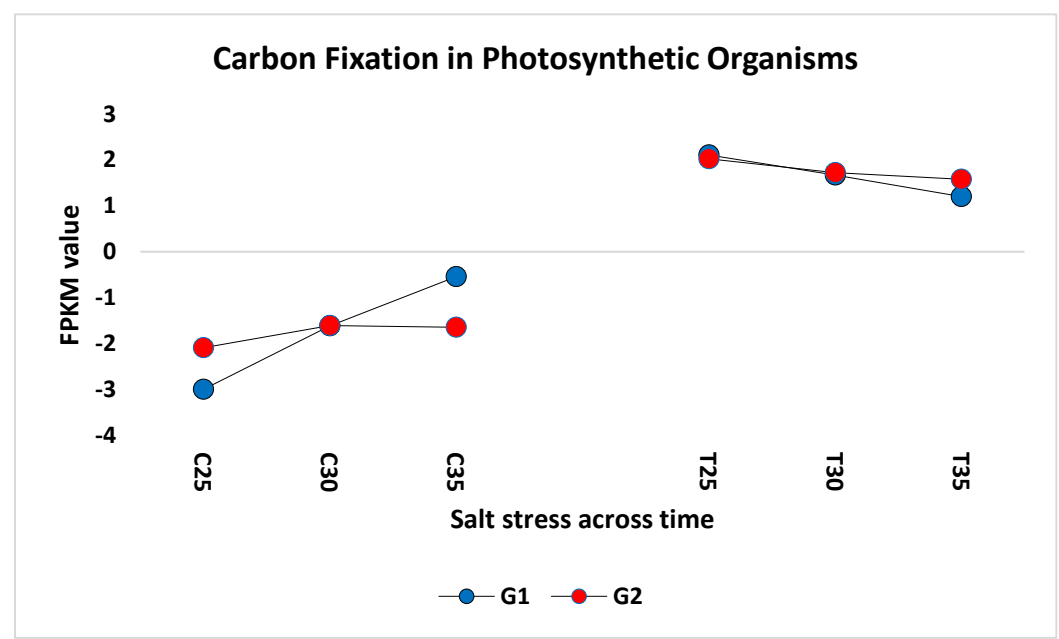

Figure 6. The performance of fructose-bisphosphate aldolase $(A L D O)(G 1)$ and transketolase (TKT) (G2) genes of "Carbon fixation in photosynthetic organisms" pathway in leaves of nonsalinized $(C)$ and salinized (T) Jojoba plants at three NaCl concentrations (50, 100, and $200 \mathrm{mM}$ ) increased incrementally with five-day intervals and harvested at the second day (days 25,30 and 35 , respectively)

Glyoxylate and dicarboxylate metabolism

Physiological analysis indicated the involvement of hydrogen peroxide $\left(\mathrm{H}_{2} \mathrm{O}_{2}\right)$ in the plant response to salt stress (Fig. 3). This molecule contributes to the cycle of mutual biosynthesis of (S)-2-hydroxy-acid oxidase//catalase of "glyoxylate and dicarboxylate metabolism" pathway (Fig. A2). The present study indicated the participation of one gene in this cycle namely $H A O$ that encodes (S)-2-hydroxy-acid oxidase (EC: 1.1.3.15) (Table 1). This gene was upregulated at 50, 100 and $200 \mathrm{mM} \mathrm{NaCl}$ (Fig. 10). The encoded enzyme participates in four pathways (Table 1), but we focused on one pathway that complement the studied physiological parameter of $\mathrm{H}_{2} \mathrm{O}_{2}$. In this pathway, (S)-2-hydroxy-acid oxidase participates in the production of $\mathrm{H}_{2} \mathrm{O}_{2}$, thus, we expect that 
overproduction of the enzyme under salt stress likely results in the increased level of $\mathrm{H}_{2} \mathrm{O}_{2}$. The latter molecule represents an avenue towards the production of catalase enzyme. Physiological analysis indicated that the level of $\mathrm{H}_{2} \mathrm{O}_{2}$ significantly reduced under 50 and $100 \mathrm{mM} \mathrm{NaCl}$ (Fig. 3), while the level of catalase activity significantly increased under these two salt concentrations (Fig. 4). These contrary results indicate that $\mathrm{H}_{2} \mathrm{O}_{2}$ level is diminished towards the production of catalase enzyme (EC: 1.11.1.6) as shown in the pathway (Fig. A2).

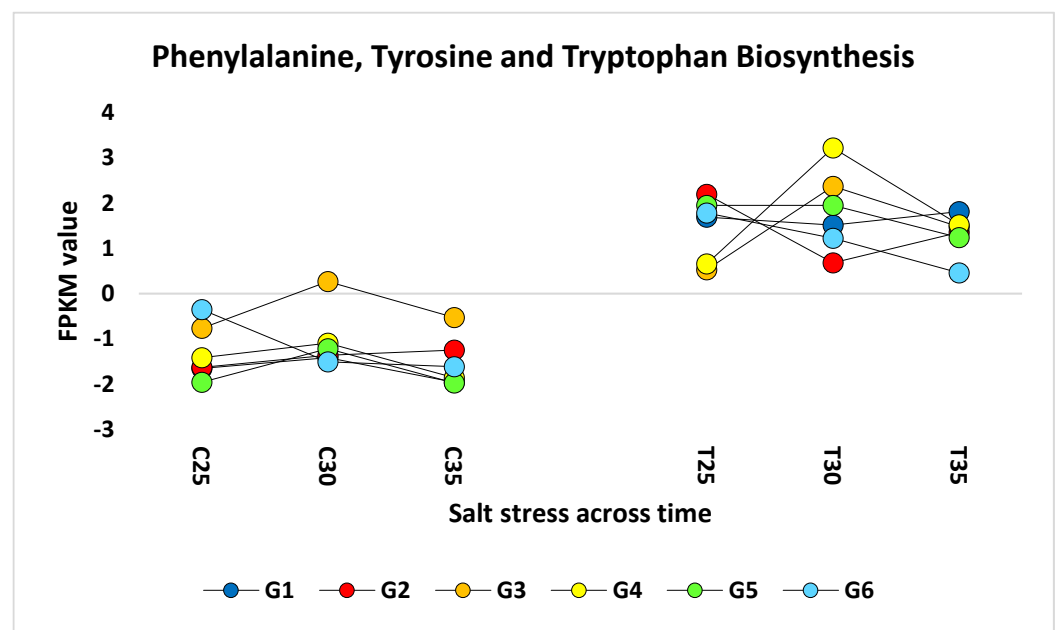

Figure 7. The performance of genes encoding metabolites in the "Phenylalanine, tyrosine and tryptophan biosynthesis" pathway in leaves of non-salinized $(C)$ and salinized $(T)$ Jojoba plants at three $\mathrm{NaCl}$ concentrations $(50,100$, and $200 \mathrm{mM}$ ) increased incrementally with five-day intervals and harvested at the second day (days 25,30 and 35, respectively). $G 1=3$-deoxy-7phosphoheptulonate synthase, G2 = 3-dehydroquinate dehydratase I, G3 = anthranilate synthase, G4 = anthranilate phosphoribosyl transferase, G5 = indole-3-glycerol phosphate synthase, G6 = tryptophan synthase

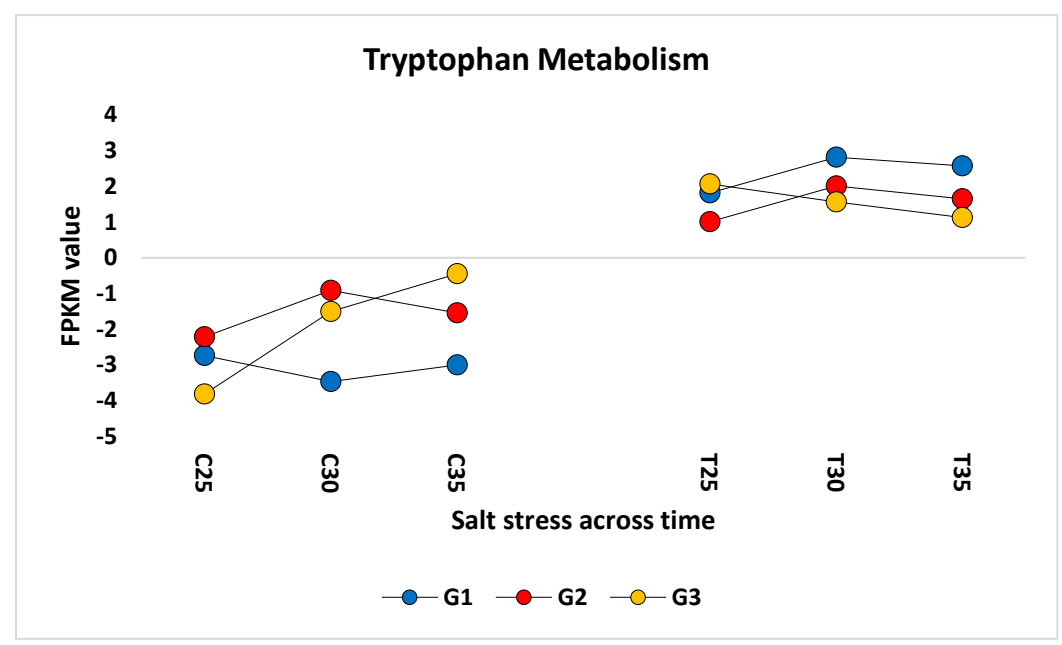

Figure 8. The performance of genes encoding metabolites in the "Tryptophan metabolism" pathway in leaves of non-salinized $(C)$ and salinized $(T)$ Jojoba plants at three $\mathrm{NaCl}$ concentrations $(50,100$, and $200 \mathrm{mM})$ increased incrementally with five-day intervals and harvested at the second day (days 25, 30 and 35, respectively). G1 = pyruvate aminotransferase, $G 2$ = indole-3-pyruvate monooxygenase, $G 3=$ amidase 


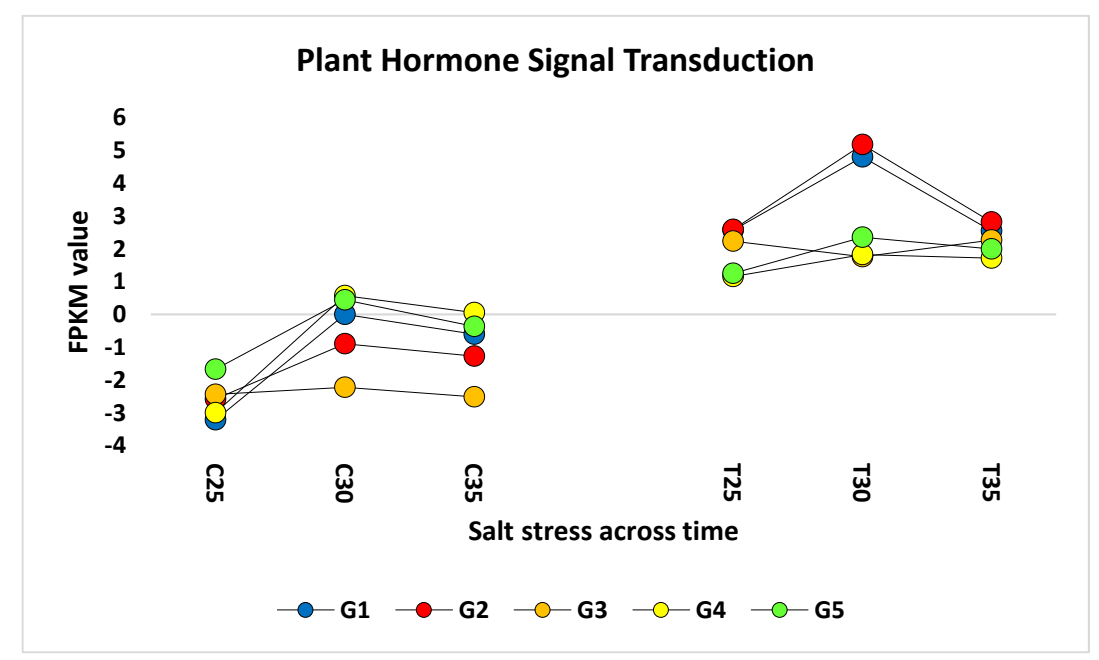

Figure 9. The performance of genes encoding metabolites in the "Plant hormone signal transduction" pathway in leaves of non-salinized $(C)$ and salinized $(T)$ Jojoba plants at three $\mathrm{NaCl}$ concentrations $(50,100$, and $200 \mathrm{mM}$ ) increased incrementally with five-day intervals and harvested at the second day (days 25, 30 and 35, respectively). G1 = Auxin-responsive protein

IAA1, G2 = Auxin response factor 1 (ARF1), G3 = transport inhibitor response 1 (TIR1),

G4 = auxin responsive GH3.3, G5 = SAUR-like auxin-responsive SAUR2

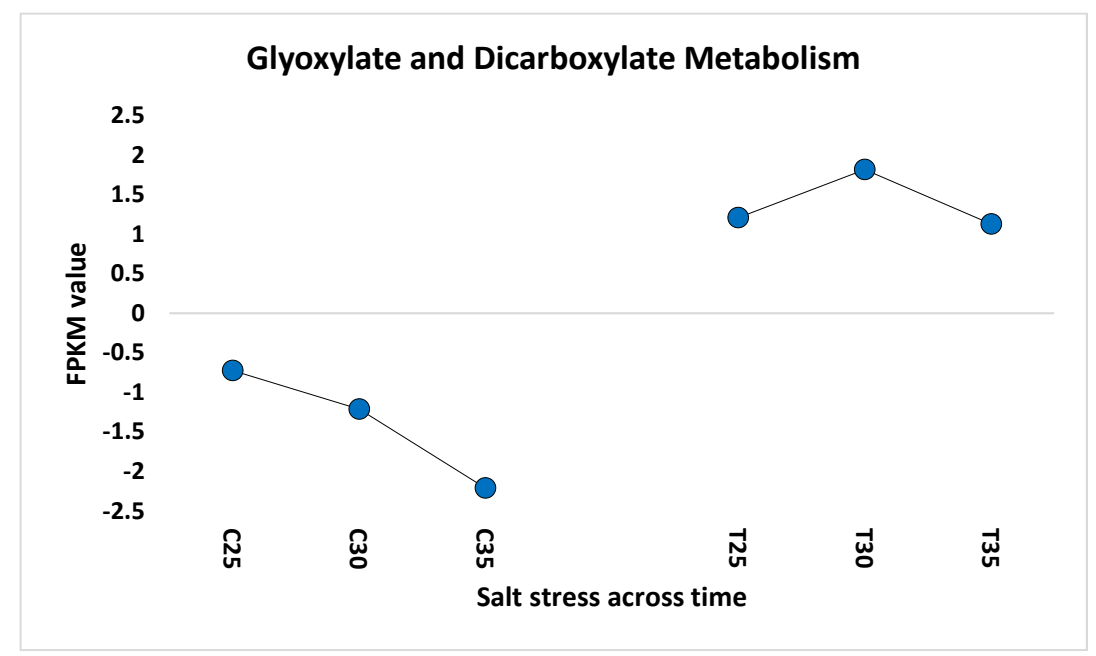

Figure 10. The performance of (S)-2-hydroxy-acid oxidase gene (HAO) in "Glyoxylate and dicarboxylate metabolism" pathway leaves of non-salinized $(C)$ and salinized $(T)$ Jojoba plants at three $\mathrm{NaCl}$ concentrations $(50,100$, and $200 \mathrm{mM}$ ) increased incrementally with five-day intervals and harvested at the second day (days 25, 30 and 35, respectively)

The (S)-2-hydroxy-acid oxidase enzyme participates in two cycles within the "glyoxylate and dicarboxylate metabolism" pathway (Fig. A2). As indicated earlier, the first cycle involves mutual production of (S)-2-hydroxy-acid oxidase//catalase. The second cycle involves the mutual production of glycolate//(S)-2-hydroxy-acid oxidase//glyoxylate. It is well-known that glycolate oxidation is catalyzed either by glycolate dehydrogenase or a glycolate oxidase (EC: 1.1.99.14), while glyoxylate reduction is catalyzed by glyoxylate reductase (NADP+) (EC: 1.1.1.26) (Fig. A7). 
Glycolate oxidase catalyzes the chemical reaction (shown in Fig. A7) by oxidizing glycolate to glyoxylate as in the following equation: $[(\mathrm{S})-2$-hydroxy acid $+\mathrm{O} 2 \rightleftharpoons 2$ oxo acid $+\mathrm{H}_{2} \mathrm{O}_{2}$ ] (Kern et al., 2020). Interestingly, the two cycles that are connected to (S)-2-hydroxy-acid oxidase in the "glyoxylate and dicarboxylate metabolism" pathway crosstalk with "carbon fixation in photosynthetic organisms" pathway via the enzyme's substrate, e.g., glycolate. Crosstalking is mainly mediated by the action of transketolase (EC: 2.2.1.1), and the two downstream enzymes namely ribose-5phosphate isomerase (EC: 5.3.1.6) and phosphoribulokinase (EC: 2.7.1.19) of "carbon fixation in photosynthetic organisms" pathway with ribulose-1,5-biphosphate exists as the intermediate metabolite (Fig. A7). The latter is converted by ribulose-bisphosphate carboxylase (EC: 4.1.1.39), then, by phosphoglycolate phosphatase (EC: 3.1.3.18) of "glyoxylate and dicarboxylate metabolism" pathway towards the production of glycolate, e.g., substrate of (S)-2-hydroxy-acid oxidase (EC: 1.1.3.15). Another route for the connection of the two pathways is mediated by the action of the two enzymes phosphoglycerate kinase (EC: 2.7.2.3) and glyceraldehyde-3-phosphate dehydrogenase (EC: 1.2.1.12) of "carbon fixation in photosynthetic organisms" pathway with glycerate-3-phosphate as an intermediate metabolite towards the production of glyceraldehyde-3-phosphate, e.g., substrate of fructose-bisphosphate aldolase (EC: 4.1.2.13). This indicates that expression of $H A O$ gene under salt stress might promote entrance to "carbon fixation in photosynthetic organisms" pathway, while expression of $A L D O$ and $T K T$ genes promote entrance to the downstream pathways of "phenylalanine, tyrosine and tryptophan biosynthesis", "tryptophan metabolism" and "plant hormone signal transduction" to confer salt stress tolerance in plants.

Ascorbate and aldarate metabolism

Physiological analysis indicated the significant increase of ascorbate peroxidase (APX) (EC: 1.11.1.11) activity at $100 \mathrm{mM} \mathrm{NaCl} \mathrm{(Fig.} \mathrm{5),} \mathrm{while} \mathrm{molecular} \mathrm{analysis}$ indicated the upregulation of the gene encoding APX at 100 and $200 \mathrm{mM} \mathrm{NaCl}$ (Fig. 11). The gene encoding APX participates in three pathways in which only one pathway was considered for further analysis (Table 1). APX converts ascorbate to monodehydro ascorbate (Fig. A3). Interestingly, "glyoxylate and dicarboxylate metabolism" pathway crosstalks with "ascorbate and aldarate metabolism" pathway with tartronate semialdehyde as the connecting intermediate metabolite (Figs. A2 and A3). This latter metabolite further interconnects with monodehydro ascorbate via APX and six preceding steps in the "ascorbate and aldarate metabolism" pathway (Fig. A3), while interconnects directly with glyoxylate via the action of tartronate-semialdehyde synthase (EC: 4.1.1.47) in the "glyoxylate and dicarboxylate metabolism" pathway (Fig. A2). Tartronate-semialdehyde is also a connecting metabolite between "glyoxylate and dicarboxylate metabolism" and "carbon fixation in photosynthetic organisms" pathways via the action of two enzymes namely 2-hydroxy-3-oxopropionate reductase (EC: 1.1.1.60) and glycerate-3-kinase (EC: 2.7.1.31).

Overall, the six pathways "carbon fixation in photosynthetic organisms", "phenylalanine, tyrosine and tryptophan biosynthesis" (Fig. A4), "tryptophan metabolism" (Fig. A5) and "plant hormone signal transduction", "ascorbate and aldarate metabolism" and "glyoxylate and dicarboxylate" were proven to crosstalk under salt stress in Jojoba to provide a mechanism by which this plant tolerates salt stress as schematically represented in Figure 12. 


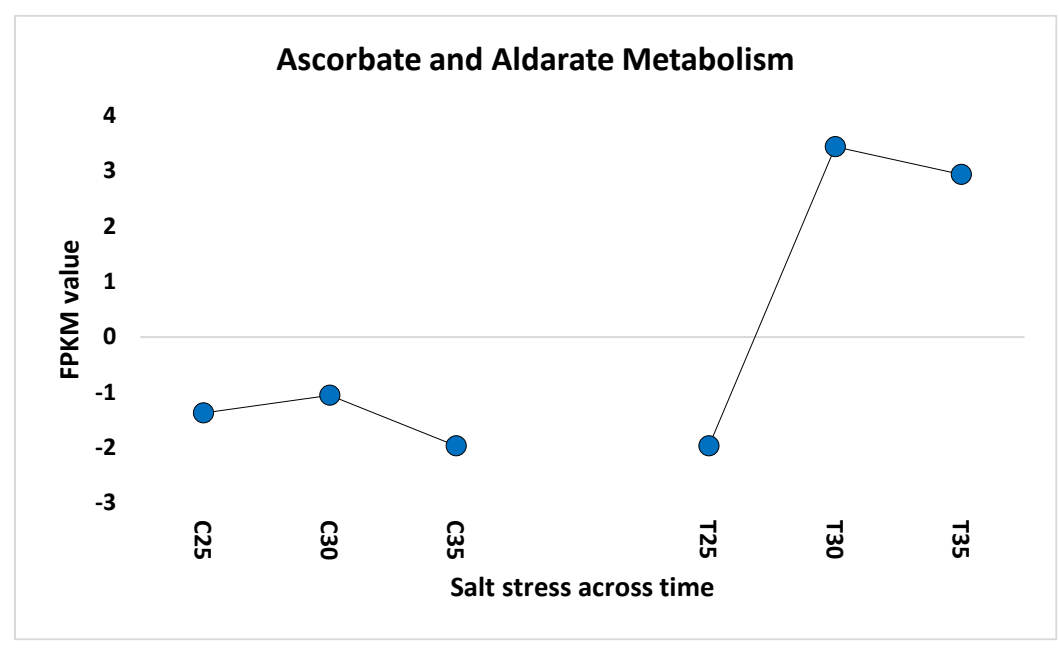

Figure 11. The performance of ascorbate peroxidase (APX) gene in the "Ascorbate and aldarate metabolism" pathway in leaves of non-salinized $(C)$ and salinized $(T)$ Jojoba plants at three $\mathrm{NaCl}$ concentrations $(50,100$, and $200 \mathrm{mM}$ ) increased incrementally with five-day intervals and harvested at the second day (days 25, 30 and 35, respectively)

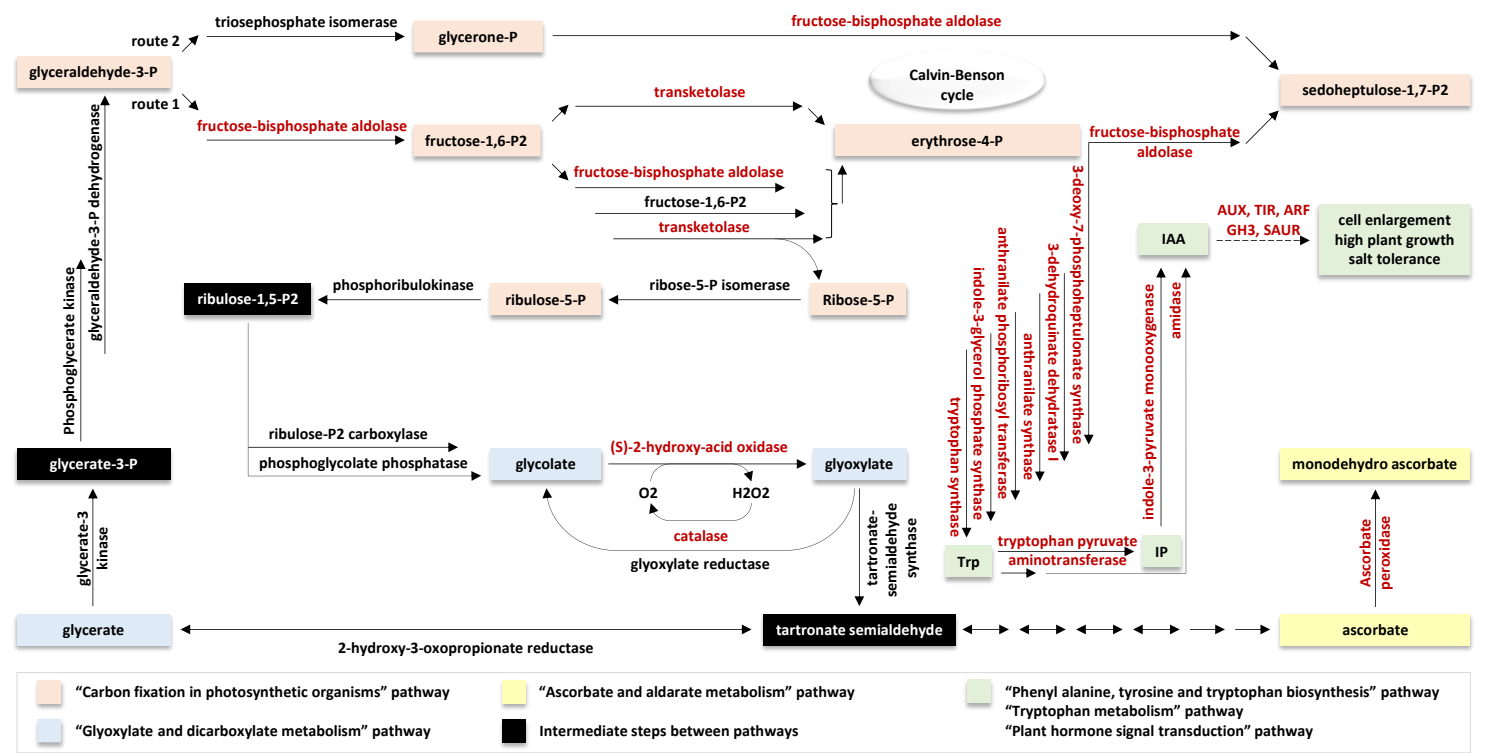

Figure 12. A schematic representation of genetic regulatory network referring to the crosstalking pathways under salt stress in Jojoba plants. Enzymes in red refer to the enriched enzymes of six pathways under salt stress based on physiological (catalase and ascorbate peroxidase) and molecular (fructose-bisphosphate aldolase, transketolase and ascorbate peroxidase) analyses. $\operatorname{Tr} p=$ tryptophan, IAA = indole acetic acid, IP = indole pyruvate

\section{Discussion}

Chlorophyll is essential for photosynthesis as it allows plants to absorb energy from light (Carter, 1996; He et al., 2020). Such solar energy has a balancing network that can adapt over long time scale to provide certain metabolic demands due to the change in environmental conditions (Walker et al., 2020). There are many emerging research in plant photosynthesis indicating that stoichiometry of interaction of light reactions with 
carbon metabolism is mandatory in regulating photosynthetic rate under adverse conditions (Sharkey, 2020). Recent work of Zhou et al. (2020) successfully engineered the transition between photosystem I (PSI) and PSII as a smart and promising way to improve efficiency of natural photosynthetic process. There are two types of chlorophyll in the photosystems of green plants namely chlorophyll-a and chlorophyll-b (Carter, 1996; Speer, 1997). Of which, chlorophyll-b was proven to act solely in light harvesting (Kume et al., 2018). Chlorophyll absorbs light mostly in the blue portion of the electromagnetic spectrum as well as in the red portion (Muneer et al., 2014). These molecules are embedded in the thylakoid membranes of chloroplasts to induce photosystems (Carter, 1996). Photosynthesis converts light energy into chemical energy that can be used as a fuel for organisms' activities. This chemical energy is stored in carbohydrate molecules, e.g., sugars, which are synthesized from carbon dioxide and water (Green and Durnford, 1996). Carbon dioxide is converted into sugars in a process called carbon fixation (Whitmarsh and Govindjee, 1999).

Carbon fixation is the process by which carbon dioxide is converted to organic compounds in photosynthetic organisms. The organic compounds are then used to store energy and considered as building blocks for other important biomolecules (Geider et al., 2001). The results in Figure $2 a$ indicate that amount of chlorophyll-a slightly reduced at $100 \mathrm{mM} \mathrm{NaCl}$ salt stress, while increased at $200 \mathrm{mM} \mathrm{NaCl}$. On the other hands, the results for chlorophyll-b and carotenoids indicated increases at $100 \mathrm{mM} \mathrm{NaCl}$ salt stress, while significant decreases at $200 \mathrm{mM} \mathrm{NaCl}$ (Fig. 2b, c). These results indicate that salt-related genes for the production of chlorophyll-a required longer time (day 30) to respond to salt stress than the time required for genes controlling the production of either chlorophyll-b or carotenoids (day 25). No significant differences were found for the production of the three pigments when plantlets exposed to $50 \mathrm{mM}$ $\mathrm{NaCl}$ for one day. This indicates that one-day exposure to salt stress is not enough time to induce salt-related genes for the production of the three pigments. Such a stepwise response of the genes for the production of the three pigments can be a mechanism of salt-stress tolerance in Jojoba.

Overall, salt-induced water stress results in the reduction of chloroplast stroma volume, thus, generation of reactive oxygen species (ROS) and inhibition of photosynthetic rate (Price and Hendry, 1991; Allen, 1995; Cha-Um and Kirdmanee, 2009). Pigment levels in Jojoba plant leaves reduced significantly at 50 and $100 \mathrm{mM}$ $\mathrm{NaCl}$ in $\mathrm{Chl}_{\mathrm{a}}$, while $\mathrm{Chl}_{\mathrm{b}}$ and charotinoids significantly reduced at the high salt concentration $(200 \mathrm{mM} \mathrm{NaCl})$. This indicates that stroma volume and photosynthetic rate were not affected at the low and intermediate levels of salt stress in Jojoba leaves. These results indicate that Jojoba tolerates moderate levels of salt stress.

Decrease in total chlorophyll content may also be observed under salinity stress due to ion accumulation and functional disorders observed during stoma opening and closure (Seemann and Critchley, 1985; Romero-Aranda, and Syvertsen, 1996; Molazem et al., 2010; Nawaz et al., 2010). Another reason for the decreased chlorophyll content under salt conditions is stated to be the result of rapid leaf maturing (Yeo et al., 1991). Decrease in chlorophyll content under salinity stress is observed more clearly in salt sensitive genotypes in comparison to cultivars with intermediate level of tolerance (such as Jojoba) (Krinsky, 1978; Seeman and Critchley, 1985; Sharkey et al., 1985; Maibangsa et al., 1999; Nafie and El-Khallal, 2000; Hayat et al., 2001; Sivakumar et al., 2002; Durai, 2006; Khan et al., 2009; Tiwari et al., 2010; Akça and Samsunlu, 2012; Ali et al., 2013; Sharkey et al., 2020). 
The results of the present study indicated that the two enzymes fructose-bisphosphate aldolase and transketolase were upregulated under salt stress referring to enhanced level of photosynthesis. The enzyme fructose-bisphosphate aldolase is among a subgroup of the larger lyase group. The aldolases can be divided into two classes depending on the type of enzyme catalysis. Type I enzymes is principally found in eukaryotes, while type II is found predominantly in bacteria and archaea (Dalby et al., 1999; Ziveri et al., 2017). Figure 6 shows an increase in the enzyme at the three salt concentrations compared to the control. In plants, "carbon fixation in photosynthetic organisms" pathway plays a crucial role in initiating complex responses to stress conditions. Dixit et al. (2001) indicated that salt-tolerant plants have enhanced energy accumulation at high salt concentrations via enhanced photosynthesis. Overall, photosynthesis adds to the ability of the plant to resist reactive oxygen species (ROS) as functional activity of chlorophyll responds negatively to ROS content.

The enzyme transketolase participates in the Calvin cycle of photosynthesis (Sax et al., 2000). Transketolase is found in animal, plant and microorganisms, whereas in plants it contains one major isoform located in the chloroplast (Henderson and Toone, 1999; Henkes et al., 2001). Henkes et al. (2001) investigated the consequences of decreased transketolase activity for primary and secondary metabolism in tobacco by transferring a construct containing an antisense sequence via genetic transformation. The results showed a local loss of chlorophyll and carotenoids in the midrib when enzyme activity inhibited by $>50 \%$, spreading onto minor veins and lamina in severely affected transformants. Consequently, decreased expression of transketolase led to a preferential decrease of sugars, whereas starch remained high until photosynthesis strongly inhibited. The decrease of chlorophyll is an indirect consequence of low transketolase activity, because it did not occur until expression strongly inhibited and many aspects of metabolism were altered. Our results showed increases in chlorophyll-b and carotenoids at $100 \mathrm{mM} \mathrm{NaCl}$, while at $200 \mathrm{mM} \mathrm{NaCl}$ for chlorophyll-a. This is because production of transketolase increases in Jojoba plant under salt stress (Fig. 7) as a mechanism to maintain the level of chlorophyll-(a,b) and carotenoids in plant leaves.

During the conversion of glycolate to glyoxylate, $\mathrm{H}_{2} \mathrm{O}_{2}$ is supposed to be intensively produced due to the action of (S)-2-hydroxy-acid oxidase that is upregulated in Jojoba under salt stress (Fig. 8). The fact is that $\mathrm{H}_{2} \mathrm{O}_{2}$ level significantly reduced in Jojoba (Fig. 3) as it is converted to $\mathrm{O}_{2}$ during the production of CAT. Accordingly, the latter significantly increased in favor of $\mathrm{H}_{2} \mathrm{O}_{2}$ reduction under salt stress in Jojoba (Fig. 4). APX significantly increased in both physiological and molecular analysis (Figs. 5 and 12, respectively). High expression of APX in Jojoba complements crosstalking of "ascorbate and aldarate metabolism" and "glyoxylate and dicarboxylate metabolism" pathways with tartronate semialdehyde stands as an intermediate step between the two pathways (Fig. 12).

$\mathrm{H}_{2} \mathrm{O}_{2}$ is the most important stable non-radical ROS (Ślesak et al., 2007; Sofo et al., 2015), without a net charge (Halliwell, 2006; Sofo et al., 2015). The amount of cellular $\mathrm{H}_{2} \mathrm{O}_{2}$, together with other ROS, is a good marker of the extent of oxidative stress. As a consequence, the balance of ascorbate peroxidase (APX), and catalase (CAT) activities, representing the main enzymatic $\mathrm{H}_{2} \mathrm{O}_{2}$ scavenging mechanism in plants, is crucial for the suppression of toxic $\mathrm{H}_{2} \mathrm{O}_{2}$ levels in a cell (Apel and Hirt, 2004; Ślesak et al., 2007; Kovalchuk, 2010; Sofo et al., 2015). CAT has the ability to scavenge ROS, which can lead to oxidative damage and damage transfer resulted from 
salt stress. If ROS accumulate in plants, light-harvesting efficiency will be affected, protein synthesis as well as signal transduction processes will slow down due to changes in osmotic pressure. Ascorbate peroxidase (APX), as well as other peroxidases, such as CAT and SOD, has the ability to scavenge ROS (Sofo et al., 2015). Activity of APX enzyme increased in Jojoba at 100 and $200 \mathrm{mM} \mathrm{NaCl}$ compared to the control (Fig. 6), which is supported by molecular analysis of the gene encoding the enzyme that showed an increase at the three salt concentrations (Fig. 12). APX is generated by tartronate semialdehyde in the "ascorbate and aldarate metabolis" pathway (Fig. 12).

$\mathrm{H}_{2} \mathrm{O}_{2}$ can also act as signal molecule in regulating plant growth, morphogenesis and development (Ślesak et al., 2007; Sofo et al., 2015), such as in auxin signaling and gravitropism of maize roots (Joo et al., 2001; Sofo et al., 2015), and in somatic embryogenesis stimulation of Lycium barbarum (Cui et al., 1999; Sofo et al., 2015). $\mathrm{H}_{2} \mathrm{O}_{2}$ has considered as an essential molecule of signal transduction in both abiotic and biotic stresses. Matsuda et al. (1994) demonstrated that application of $\mathrm{H}_{2} \mathrm{O}_{2}$ at low concentrations induces stress tolerance in plants due to the induction of the synthesis of certain substances similar to other normally synthesized during chilling stress (Sofo et al., 2015). The effects of $\mathrm{NaCl}$ on the balance of $\mathrm{H}_{2} \mathrm{O}_{2}$ level and CAT activity were previously studied in diverse groups of plants, such as unicellular alga, e.g., Chlorella sp., aquatic macrophyte, e.g., Najas graminea, and mangrove plant, e.g., Suaeda maritime. All of these organisms showed high tolerance to $\mathrm{NaCl}$ as CAT activity increased significantly in response to high $\mathrm{NaCl}$ treatment (Mallik et al., 2011; Sofo et al., 2015). Results of the latter studies, in addition of the present study, support the influence of $\mathrm{H}_{2} \mathrm{O}_{2}$ at low concentrations in inducing stress tolerance.

Pathways "phenylalanine, tyrosine and tryptophan biosynthesis" and "tryptophan metabolism" likely crosstalk towards production of tryptophan, then, production of the auxin indole acetic acid (or IAA). "tryptophan metabolism" pathway crosstalk with "plant hormone signal transduction" pathway in which tryptophan produced from "phenylalanine, tyrosine and tryptophan biosynthesis" pathway is metabolized towards production of IAA via two-step avenue (Fig. 12). Then, auxin provokes other downstream pathway namely "plant hormone signal transduction" to strengthen plant's ability to survive and maintain proper growth rates under stress conditions (Fig. 12). Towards the route downstream auxin production, a battery of metabolites are produced under stress condition, e.g., auxin/indole acetic acid (or AUX/IAA), auxin response factors (or ARFs), E3 ubiquitin ligase SCF ${ }^{\mathrm{TIR} 1}$ (or TIR1), Gretchen Hagen 3 (or GH3), AUX/LAX (or LAX) and small auxin-up RNA (or SAUR). Actions of these auxinresponsive metabolites combine to enlarge cells and improve plant growth under salt stress. IAA signaling is controlled by complex ARFs and interacting repressors of AUX/IAA proteins (Gray et al., 2001). ARFs binds promoter elements of auxinresponsive genes $L A X$ and $S A U R$, while AUX/IAA proteins bind ARFs to block their action (Ulmasov et al., 1997a, b). TIR1 enzyme is the main contributor to AUX/IAA protein degradation as it activates ARFs and derepresses downstream auxin responsive pathways, thus promotes plant growth and development (Gray et al., 2001). GH3 is a class of auxin-induced conjugating enzymes that secures homeostasis and regulation of active form of auxin in the cell as well as blocks action of excessively available auxin (Paponov et al., 2008). Activated forms of ARFs stimulate SAUR that acts as a regulator of cell elongation (Knauss et al., 2003) and a stimulator of shoot elongation (Paponov et al., 2008). 


\section{Conclusion}

In conclusion, we assume we have widened our knowledge of the physiological and molecular mechanisms underlying salt stress tolerance in Jojoba. This information can help using this plant as a source of biodiesel in salinized soil or areas of scarce water supply. The recovered information can also help in the development of new economically important crop plants with improved salt tolerance via metabolic engineering. The information can promote the possible cultivation of this plant as a source of biodiesel in moderately salinized soil or areas of water scarce.

\section{REFERENCES}

[1] Abd-Allah, E. F., Hashem, A., Alqarawi, A. A., Alwathnani, H. A. (2015): Alleviation of adverse impact of cadmium stress in sunflower (Helianthus annuus L.) by arbuscular mycorrhizal fungi. - Pak. J. Bot 47(2): 785-795.

[2] Aebi, H. (1984): Catalase in vitro. - Methods in Enzymology 105(121-126).

[3] Akça, Y. A. Ş. A. R., Samsunlu, E. (2012): The effect of salt stress on growth, chlorophyll content, proline and nutrient accumulation, and $\mathrm{K} / \mathrm{Na}$ ratio in walnut. - Pak. J. Bot 44(5): 1513-1520.

[4] Ali, E. F., Bazaid, S., Hassan, F. A. S. (2013): Salt effects on growth and leaf chemical constituents of Simmondsia chinensis (Link) Schneider. - J Med Plants Stud 1(3): 22-4.

[5] Allen, R. D. (1995): Dissection of oxidative stress tolerance using transgenic plants. - Plant Physiology 107(4): 1049.

[6] Al-Obaidi, J. R., Halabi, M. F., AlKhalifah, N. S., Asanar, S., Al-Soqeer, A. A., Attia, M. F. (2017): A review on plant importance, biotechnological aspects, and cultivation challenges of jojoba plant. - Biological Research 50. DOI: 10.1186/s40659-017-0131-x.

[7] Apel, K., Hirt, H. (2004): Reactive oxygen species: metabolism, oxidative stress, and signal transduction. - Annu. Rev. Plant Biol. 55: 373-399.

[8] Bafeel, S. O., Galal, H. K., Basha, A. Z. (2016): Effect of seawater irrigation on growth and some metabolites of jojoba plants. - Am.-Eurasian J. Agric. Environ. Sci 16: 49-59.

[9] Bahieldin, A., Atef, A., Sabir, J. S., Gadalla, N. O., Edris, S., Alzohairy, A. M., ... Hassan, S. M. (2015): RNA-Seq analysis of the wild barley (H. spontaneum) leaf transcriptome under salt stress. - Comptes Rendus Biologies 338(5): 285-297.

[10] Bolger, A. M., Lohse, M., Usadel, B. (2014): Trimmomatic: a flexible trimmer for Illumina sequence data. - Bioinformatics 30(15): 2114-2120.

[11] Bowler, C., Fluhr, R. (2000): The role of calcium and activated oxygens as signals for controlling cross-tolerance. - Trends in Plant Science 5(6): 241-246.

[12] Cakmak, I., Marschner, H. (1992): Magnesium deficiency and high light intensity enhance activities of superoxide dismutase, ascorbate peroxidase, and glutathione reductase in bean leaves. - Plant Physiology 98(4): 1222-1227.

[13] Cao, D., Liu, Y., Ma, L., Jin, X., Guo, G., Tan, R., ... Liu, W. (2018): Transcriptome analysis of differentially expressed genes involved in selenium accumulation in tea plant (Camellia sinensis). - PloS ONE 13(6): e0197506.

[14] Carter, J. S. (1996): Photosynthesis. - University of Cincinnati, Cincinnati, OH.

[15] Cha-Um, S., Kirdmanee, C. (2009): Effect of salt stress on proline accumulation, photosynthetic ability and growth characters in two maize cultivars. - Pak. J. Bot 41(1): 8798.

[16] Cui, K., Gengsheng, X., Xinmin, L., Gengmei, X., Yafu, W. (1999): Effect of hydrogen peroxide on somatic embryogenesis of Lycium barbarum L. - Plant Science 146(1): 9-16. 
[17] Dalby, A., Dauter, Z., Littlechild, J. A. (1999): Crystal structure of human muscle aldolase complexed with fructose 1 6-bisphosphate: mechanistic implications. - Protein Science 8(2): 291-297.

[18] Dixit, V., Pandey, V., Shyam, R. (2001): Differential antioxidative responses to cadmium in roots and leaves of pea (Pisum sativum L. cv. Azad). - Journal of Experimental Botany 52(358): 1101-1109.

[19] Durai, R. (2006): Physiological approaches to alleviate drought in sugarcane. - Cooperative Sugar 37(10): 31.

[20] Garber, M., Grabherr, M. G., Guttman, M., Trapnell, C. (2011): Computational methods for transcriptome annotation and quantification using RNA-seq. - Nature Methods 8(6): 469477.

[21] Geider, R. J., Delucia, E. H., Falkowski, P. G., Finzi, A. C., Grime, J. P., Grace, J., ... Platt, T. (2001): Primary productivity of planet earth: biological determinants and physical constraints in terrestrial and aquatic habitats. - Global Change Biology 7(8): 849-882.

[22] Gray, W. M., Kepinski, S., Rouse, D., Leyser, O., Estelle, M. (2001): Auxin regulates SCF TIR1-dependent degradation of AUX/IAA proteins. - Nature 414(6861): 271-276.

[23] Green, B. R., Durnford, D. G. (1996): The chlorophyll-carotenoid proteins of oxygenic photosynthesis. - Annual Review of Plant Biology 47(1): 685-714.

[24] Hajrah, N. H., Obaid, A. Y., Atef, A., Ramadan, A. M., Arasappan, D., Nelson, C. A., ... Makki, R. M. (2017): Transcriptomic analysis of salt stress responsive genes in Rhazya stricta. - PloS ONE 12(5): e0177589.

[25] Halliwell, B. (2006): Reactive species and antioxidants. Redox biology is a fundamental theme of aerobic life. - Plant Physiology 141(2): 312-322.

[26] Hayat, S., Ahmad, A., Mobin, M., Fariduddin, Q., Azam, Z. M. (2001): Carbonic anhydrase, photosynthesis, and seed yield in mustard plants treated with phytohormones. Photosynthetica 39(1): 111-114.

[27] He, Z. S., Tang, R., Li, M. J., Jin, M. R., Xin, C., Liu, J. F., Hong, W. (2020): Response of Photosynthesis and Chlorophyll Fluorescence Parameters of Castanopsis kawakamii Seedlings to Forest Gaps. - Forests 11(1): 21.

[28] Hend, A., Abeer, A., Allah, A. (2015): Role of enzymatic and non enzymatic antioxidant in ameliorating salinity induced damage in Nostoc muscorum. - Pakistan Journal of Botany 47(6): 2435-2442.

[29] Henderson, D. P., Toone, E. J. (1999): Aldolases. - In: Barton, D. et al. (eds.) Comprehensive Natural Products Chemistry. Elsevier, Amsterdam, po. 367-440.

[30] Henkes, S., Sonnewald, U., Badur, R., Flachmann, R., Stitt, M. (2001): A small decrease of plastid transketolase activity in antisense tobacco transformants has dramatic effects on photosynthesis and phenylpropanoid metabolism. - The Plant Cell 13(3): 535-551.

[31] Hiscox, J. D., Israelstam, G. F. (1979): A method for the extraction of chlorophyll from leaf tissue without maceration. - Canadian Journal of Botany 57(12): 1332-1334.

[32] Jain, M. (2012): Next-generation sequencing technologies for gene expression profiling in plants. - Briefings in Functional Genomics 11(1): 63-70.

[33] Joo, J. H., Bae, Y. S., Lee, J. S. (2001): Role of auxin-induced reactive oxygen species in root gravitropism. - Plant Physiology 126(3): 1055-1060.

[34] Kawa, D., Testerink, C. (2017): Regulation of mRNA decay in plant responses to salt and osmotic stress. - Cellular and Molecular Life Sciences 74(7): 1165-1176.

[35] Kern, R., Facchinelli, F., Delwiche, C., Weber, A. P., Bauwe, H., Hagemann, M. (2020): Evolution of photorespiratory glycolate oxidase among Archaeplastida. - Plants 9(1): 106.

[36] Khan, M. A., Shirazi, M. U., Khan, M. A., Mujtaba, S. M., Islam, E., Mumtaz, S., ... Ashraf, M. Y. (2009): Role of proline, K/Na ratio and chlorophyll content in salt tolerance of wheat (Triticum aestivum L.). - Pak. J. Bot 41(2): 633-638.

[37] Knauss, S., Rohrmeier, T., Lehle, L. (2003): The auxin-induced maize gene ZmSAUR2 encodes a short-lived nuclear protein expressed in elongating tissues. - Journal of Biological Chemistry 278(26): 23936-23943. 
[38] Kovalchuk, I. (2010): Multiple Roles of Radicals in Plants. - In: Gupta, S. D. (ed.) Reactive Oxygen Species and Antioxidants in Higher Plants. CRC, Boca Raton, FL, pp. 31-44.

[39] Krinsky, N. I. (1978): Non-photosynthetic functions of carotenoids. - Philosophical Transactions of the Royal Society of London. B, Biological Sciences 284(1002): 581-590.

[40] Kume, A., Akitsu, T., Nasahara, K. N. (2018): Why is chlorophyll b only used in lightharvesting systems? - Journal of Plant Research 131(6): 961-972.

[41] Liang, W., Ma, X., Wan, P., Liu, L. (2018): Plant salt-tolerance mechanism: a review. Biochemical and Biophysical Research Communications 495(1): 286-291.

[42] Maibangsa, S., Thangaraj, M., Roy, S. (1999): Alleviation of low irradiance stress in rice (Oryza sativa L.) by growth regulators. - Annals of Plant Physiology 13(2): 133-142.

[43] Mallik, S., Nayak, M., Sahu, B. B., Panigrahi, A. K., Shaw, B. P. (2011): Response of antioxidant enzymes to high $\mathrm{NaCl}$ concentration in different salt-tolerant plants. - Biologia Plantarum 55(1): 191-195.

[44] Martin, J. A., Wang, Z. (2011): Next-generation transcriptome assembly. - Nature Reviews Genetics 12(10): 671-682.

[45] Matsuda, Y., Okuda, T., Sagisaka, S. (1994): Regulation of protein synthesis by hydrogen peroxide in crowns of winter wheat. - Bioscience, Biotechnology, and Biochemistry 58(5): 906-909.

[46] Min, X. J., Butler, G., Storms, R., Tsang, A. (2005): OrfPredictor: predicting protein-coding regions in EST-derived sequences. - Nucleic Acids Research 33(suppl_2): W677-W680.

[47] Mittler, R. (2002): Oxidative stress, antioxidants and stress tolerance. - Trends in Plant Science 7(9): 405-410.

[48] Molazem, D., Qurbanov, E. M., Dunyamaliyev, S. A. (2010): Role of proline, Na and chlorophyll content in salt tolerance of corn (Zea mays L.). - American-Eurasian Journal of Agricultural and Environmental Science 9(3): 319-324.

[49] Mukherjee, S. P., Choudhuri, M. A. (1983): Implications of water stress-induced changes in the levels of endogenous ascorbic acid and hydrogen peroxide in Vigna seedlings. Physiologia Plantarum 58(2): 166-170.

[50] Muneer, S., Kim, E. J., Park, J. S., Lee, J. H. (2014): Influence of green, red and blue light emitting diodes on multiprotein complex proteins and photosynthetic activity under different light intensities in lettuce leaves (Lactuca sativa L.). - International Journal of Molecular Sciences 15(3): 4657-4670.

[51] Munns, R. (2002): Comparative physiology of salt and water stress. - Plant, Cell \& Environment 25(2): 239-250.

[52] Nafie, E. M., El-Khallal, S. M. (2000): Effect of brassinolide application on growth certain metabolic activities and yield of tomato. - Egyptian Journal of Physiological Sciences 24(1): 103-117.

[53] Nakano, Y., Asada, K. (1981): Hydrogen peroxide is scavenged by ascorbate-specific peroxidase in spinach chloroplasts. - Plant and Cell Physiology 22(5): 867-880.

[54] Nawaz, K., Talat, A., Hussain, K., Majeed, A. (2010): Induction of salt tolerance in two cultivars of sorghum (Sorghum bicolor L.) by exogenous application of proline at seedling stage. - World Applied Sciences Journal 10(1): 93-99.

[55] Nejat, N., Ramalingam, A., Mantri, N. (2018): Advances in Transcriptomics of Plants. - In: Varshney, R K. et al. (eds.) Plant Genetics and Molecular Biology. Springer, Cham, pp. 161-185.

[56] Panda, S. K., Khan, M. H. (2004): Changes in growth and superoxide dismutase activity in Hydrilla verticillata L. under abiotic stress. - Brazilian Journal of Plant Physiology 16(2): 115-118.

[57] Paponov, I. A., Paponov, M., Teale, W., Menges, M., Chakrabortee, S., Murray, J. A., Palme, K. (2008): Comprehensive transcriptome analysis of auxin responses in Arabidopsis. - Molecular Plant 1(2): 321-337.

[58] Passerini, E., Lombardo, P. (2000): Cosmetics. - Cosmet News 22: 396-398. 
[59] Price, A. H., Hendry, G. A. F. (1991): Iron-catalysed oxygen radical formation and its possible contribution to drought damage in nine native grasses and three cereals. - Plant, Cell \& Environment 14(5): 477-484.

[60] Robinson, M. D., McCarthy, D. J., Smyth, G. K. (2010): edgeR: a Bioconductor package for differential expression analysis of digital gene expression data. - Bioinformatics 26(1): 139-140.

[61] Romero-Aranda, R., Syvertsen, J. P. (1996): The influence of foliar-applied urea nitrogen and saline solutions on net gas exchange of citrus leaves. - Journal of the American Society for Horticultural Science 121(3): 501-506.

[62] Sailaja, B., Mangrauthia, S. K., Sarla, N., Voleti, S. R. (2014): Transcriptomics of Heat Stress in Plants. - In: Ahmad, P. et al (eds.) Improvement of Crops in the Era of Climatic Changes. - Springer, New York, pp. 49-89.

[63] Sax, C. M., Kays, W. T., Salamon, C., Chervenak, M. M., Xu, Y. S., Piatigorsky, J. (2000): Transketolase gene expression in the cornea is influenced by environmental factors and developmentally controlled events. - Cornea 19(6): 833-841.

[64] Seemann, J. R., Critchley, C. (1985): Effects of salt stress on the growth, ion content, stomatal behaviour and photosynthetic capacity of a salt-sensitive species, Phaseolus vulgaris L. - Planta 164(2): 151-162.

[65] Shah, K., Kumar, R. G., Verma, S., Dubey, R. S. (2001): Effect of cadmium on lipid peroxidation, superoxide anion generation and activities of antioxidant enzymes in growing rice seedlings. - Plant Science 161(6): 1135-1144.

[66] Sharkey, T. D. (1985): Photosynthesis in intact leaves of C 3 plants: physics, physiology and rate limitations. - The Botanical Review 51(1): 53-105.

[67] Sharkey, T. D. (2020): Emerging research in plant photosynthesis. - Emerging Topics in Life Sciences 4(2): 137-150.

[68] Sivakumar, R., Pathmanaban, G., Kalarani, M. K., Vanangamudi, M., Srinivasan, P. S. (2002): Effect of foliar application of growth regulators on biochemical attributes and grain yield in pearl millet. - Indian Journal of Plant Physiology 7(1): 79-82.

[69] Ślesak, I., Libik, M., Karpinska, B., Karpinski, S., Miszalski, Z. (2007): The role of hydrogen peroxide in regulation of plant metabolism and cellular signalling in response to environmental stresses. - Acta Biochimica Polonica 54(1): 39-50.

[70] Sofo, A., Scopa, A., Nuzzaci, M., Vitti, A. (2015): Ascorbate peroxidase and catalase activities and their genetic regulation in plants subjected to drought and salinity stresses. International Journal of Molecular Sciences 16(6): 13561-13578.

[71] Speer, B. R. (1997): Photosynthetic pigments. UCMP Glossary (online). - University of California, Berkeley Museum of Paleontology. Accessed on April 27, 2007.

[72] Su, X., Howell, A. B., D'Souza, D. H. (2010): Antiviral effects of cranberry juice and cranberry proanthocyanidins on foodborne viral surrogates - a time dependence study in vitro. - Food microbiology 27(8): 985-991.

[73] Sumanta, N., Haque, C. I., Nishika, J., Suprakash, R. (2014): Spectrophotometric analysis of chlorophylls and carotenoids from commonly grown fern species by using various extracting solvents. - Res J Chem Sci 2231 606X.

[74] Tiwari, J. K., Munshi, A. D., Kumar, R., Pandey, R. N., Arora, A., Bhat, J. S., Sureja, A. K. (2010): Effect of salt stress on cucumber: $\mathrm{Na}+-\mathrm{K}+$ ratio, osmolyte concentration, phenols and chlorophyll content. - Acta Physiologiae Plantarum 32(1): 103-114.

[75] Ueda, A., Kathiresan, A., Bennett, J., Takabe, T. (2006): Comparative transcriptome analyses of barley and rice under salt stress. - Theoretical and Applied Genetics 112(7): 1286-1294.

[76] Ulmasov, T., Hagen, G., Guilfoyle, T. J. (1997a). ARF1, a transcription factor that binds to auxin response elements. - Science 276(5320): 1865-1868.

[77] Ulmasov, T., Murfett, J., Hagen, G., Guilfoyle, T. J. (1997b). Aux/IAA proteins repress expression of reporter genes containing natural and highly active synthetic auxin response elements. - The Plant Cell 9(11): 1963-1971. 
[78] Walker, B. J., Kramer, D. M., Fisher, N., Fu, X. (2020): Flexibility in the energy balancing network of photosynthesis enables safe operation under changing environmental conditions. - Plants 9(3): 301.

[79] Wang, Z., Gerstein, M., Snyder, M. (2009): RNA-Seq: a revolutionary tool for transcriptomics. - Nature Reviews Genetics 10(1): 57-63.

[80] Whitmarsh, J., Govindjee (1999): The Photosynthetic Process. - In: Singhal, G. S., Renger, G., Sopory, S. K., Irrgang, K.-D., Govindjee (eds.) Concepts in Photobiology: Photosynthesis and Photomorphogenesis. Springer, Dordrecht.

[81] Wu, Q. S., Zou, Y. N., Abd-Allah, E. F. (2014): Mycorrhizal Association and ROS in Plants. - In: Ahmad, P. (ed.) Oxidative Damage to Plants. Academic Press, Cambridge, MA, pp. 453-475.

[82] Yeo, A. R., Lee, A. S., Izard, P., Boursier, P. J., Flowers, T. J. (1991): Short-and long-term effects of salinity on leaf growth in rice (Oryza sativa L.). - Journal of Experimental Botany 42(7): 881-889.

[83] Zhou, X., Zeng, Y., Tang, Y., Huang, Y., Lv, F., Liu, L., Wang, S. (2020): Artificial regulation of state transition for augmenting plant photosynthesis using synthetic lightharvesting polymer materials. - Science Advances 6(35): eabc5237.

[84] Ziveri, J., Tros, F., Guerrera, I. C., Chhuon, C., Audry, M., Dupuis, M., ... Cahoreau, E. (2017): The metabolic enzyme fructose-1 6-bisphosphate aldolase acts as a transcriptional regulator in pathogenic Francisella. - Nature Communications 8(1): 1-15. 


\section{APPENDIX}

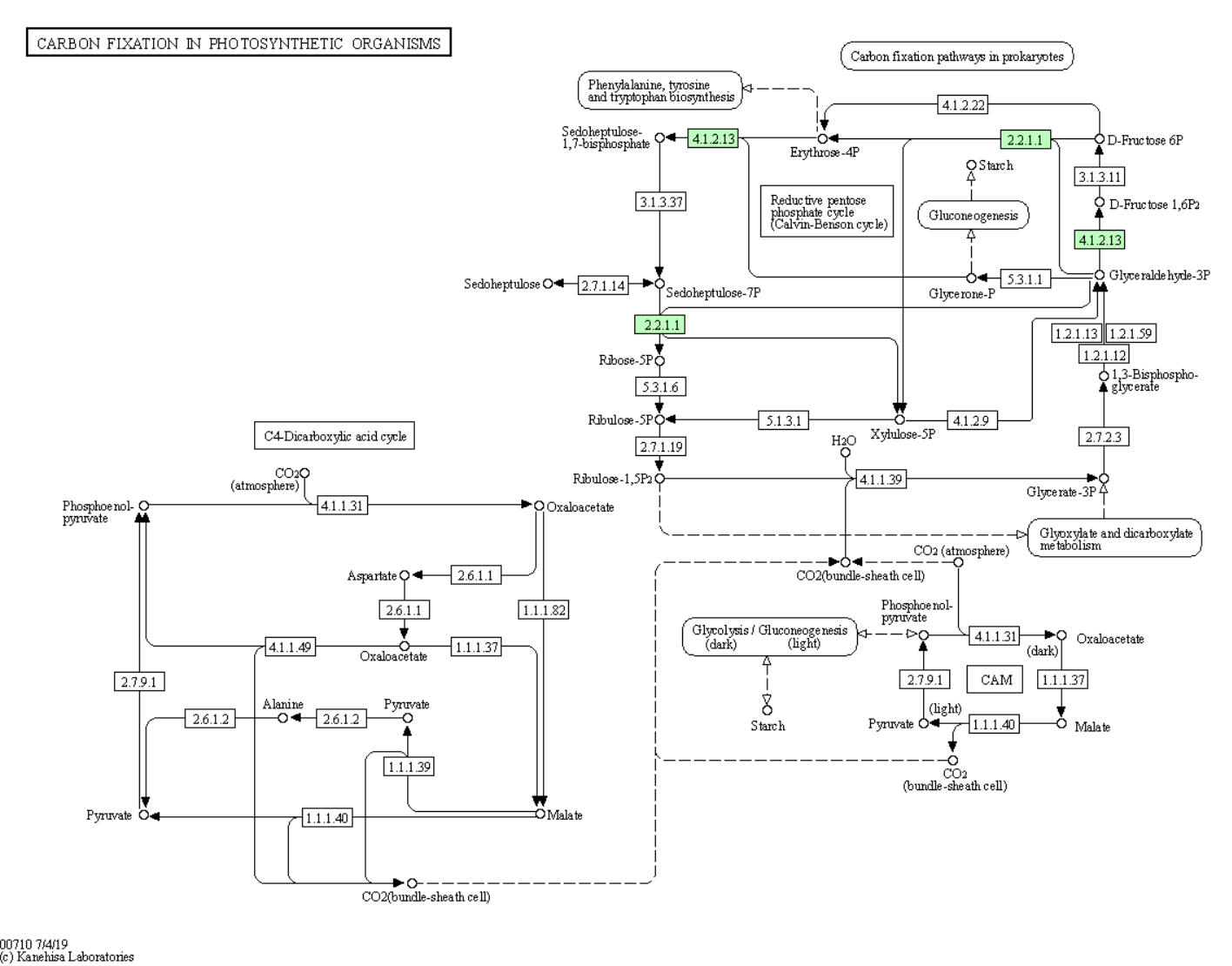

Figure A1. Enriched metabolites in the "Carbon fixation in photosynthetic organisms" pathway due to salt stress (200 $\mathrm{mM} \mathrm{NaCl}$ ) in leaves of Jojoba plant. Colored boxes refer to enriched enzyme(s) under the stress 


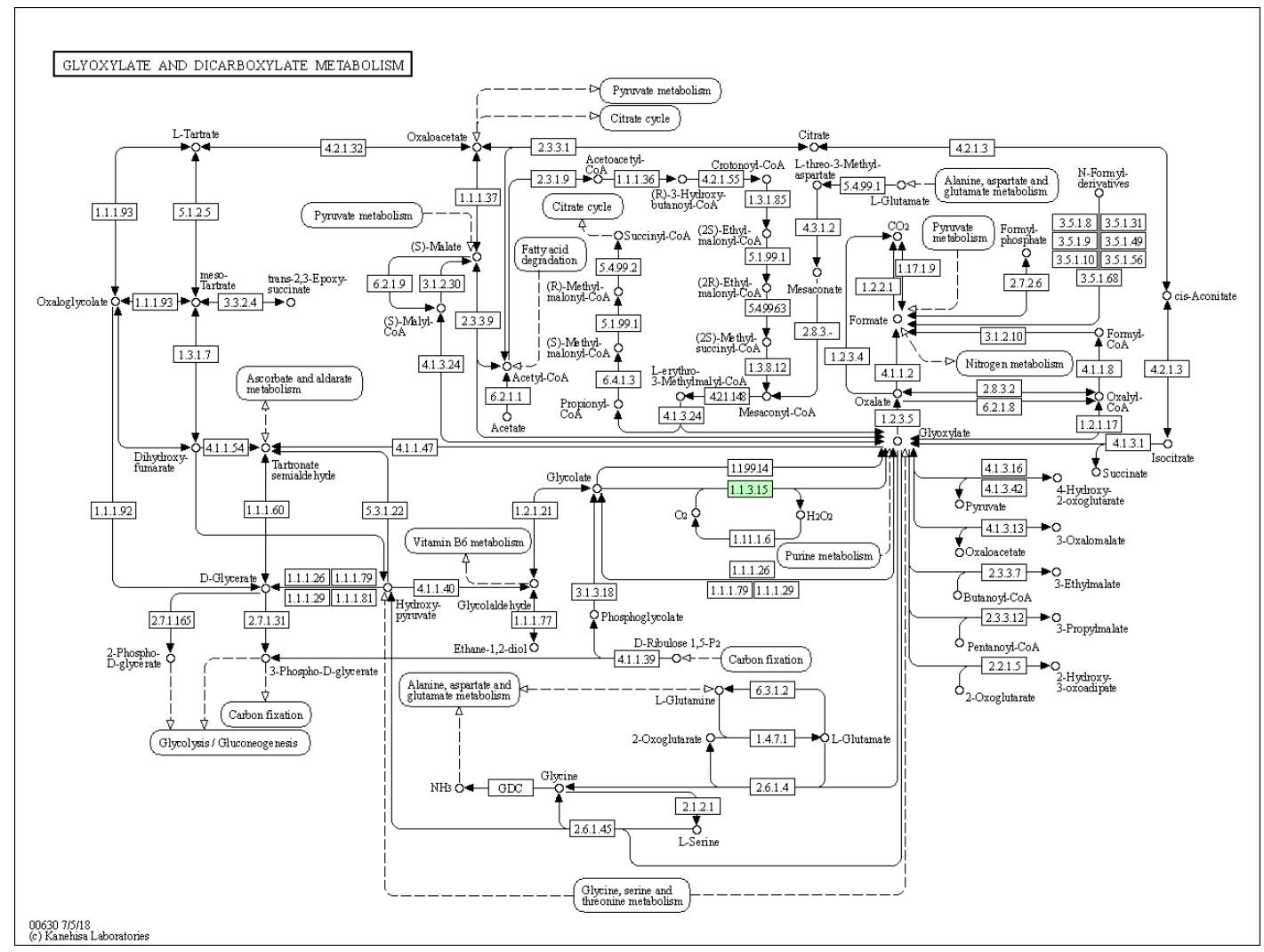

Figure A2. Enriched metabolites in the "Glyoxylate and dicarboxylate metabolism" pathway due to salt stress (200 $\mathrm{mM} \mathrm{NaCl}$ ) in leaves of Jojoba plant. Colored boxes refer to enriched enzyme(s) under the stress

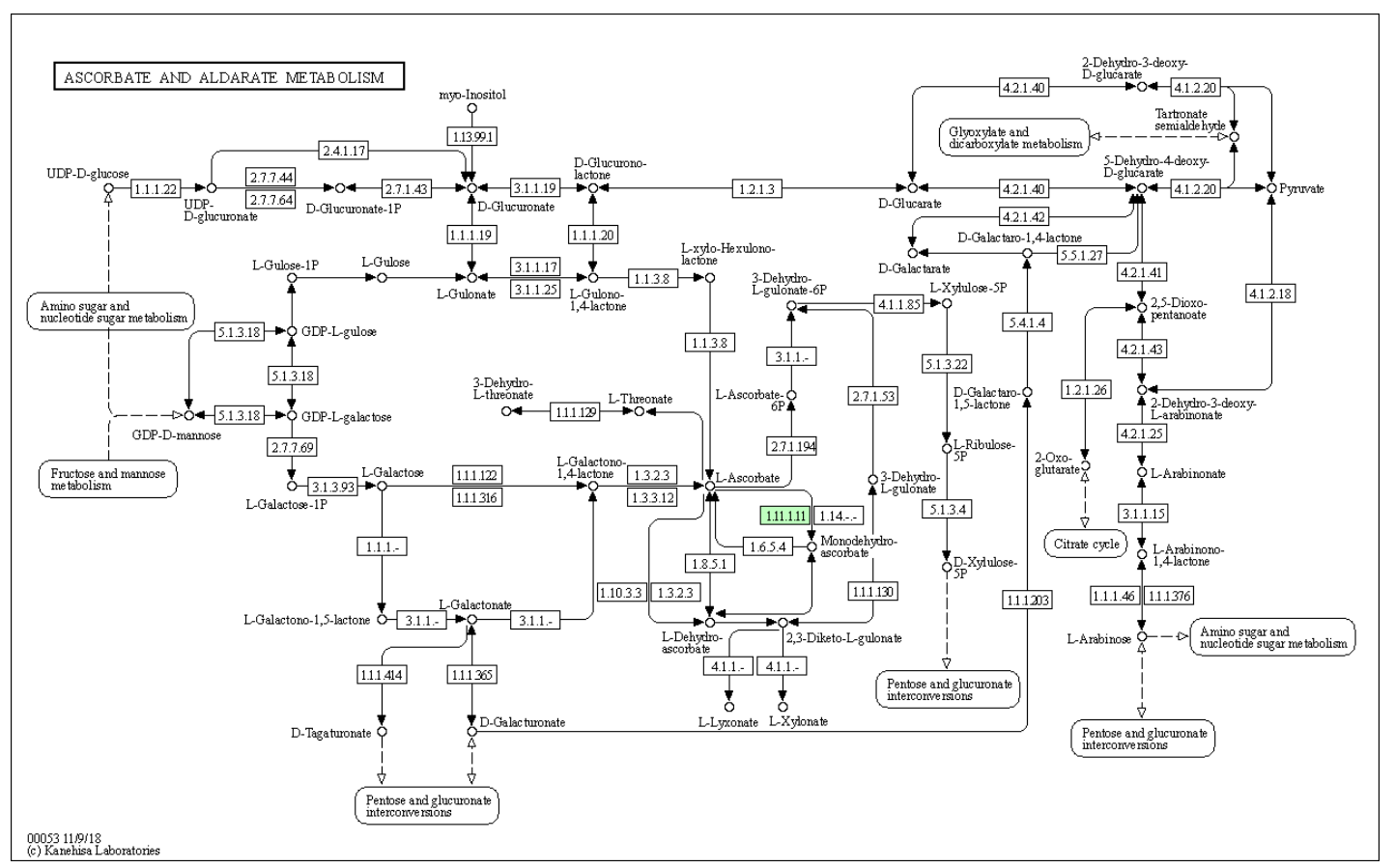

Figure A3. Enriched metabolites in the "Ascorbate and aldarate metabolism" pathway due to salt stress $(200 \mathrm{mM} \mathrm{NaCl})$ in leaves of Jojoba plant. Colored boxes refer to enriched enzyme $(\mathrm{s})$ under the stress 


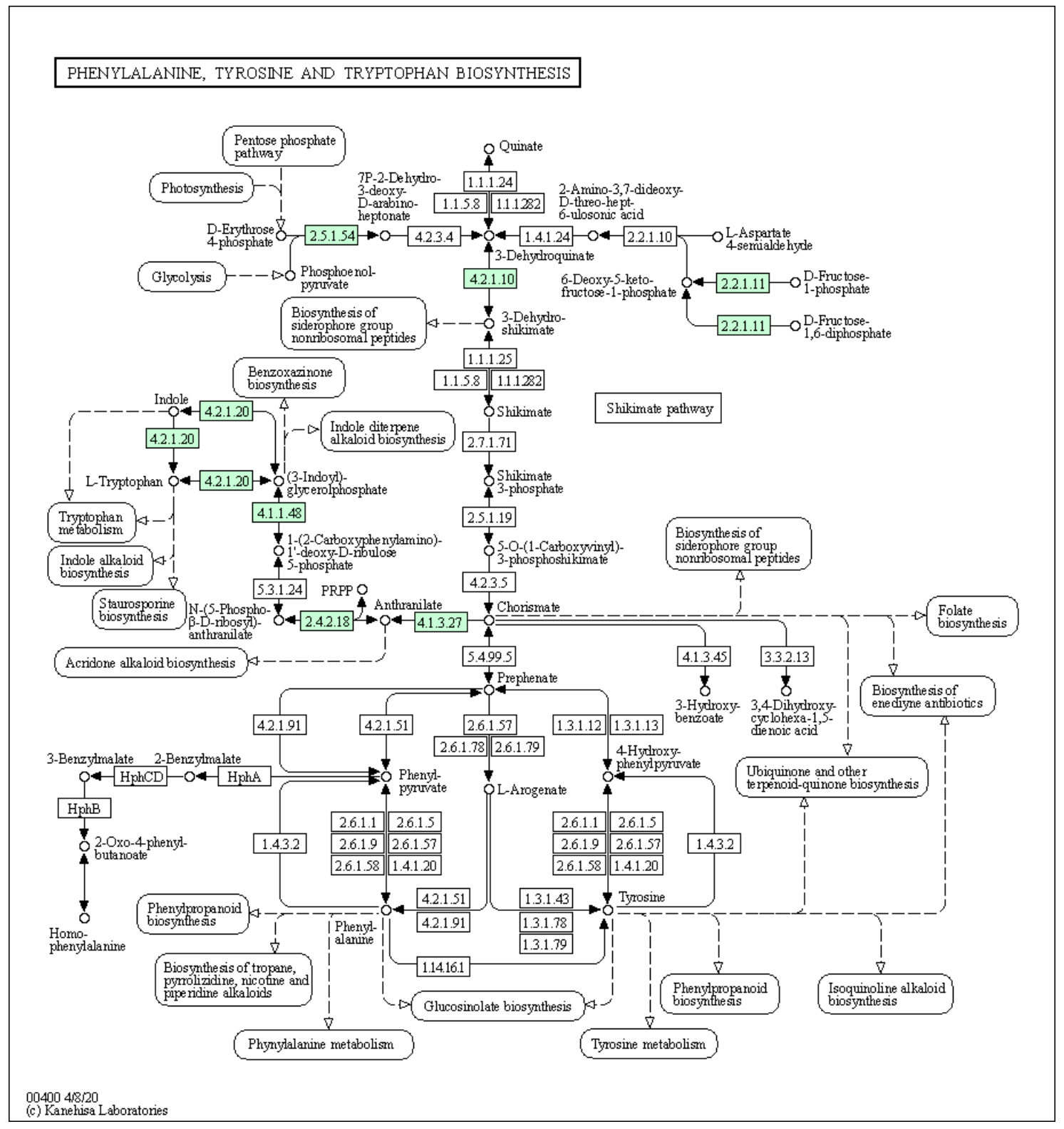

Figure A4. Enriched metabolites in the "Phenylalanine, tyrosine and tryptophan biosynthesis" pathway due to salt stress ( $200 \mathrm{mM} \mathrm{NaCl}$ ) in leaves of Jojoba plant. Colored boxes refer to enriched enzyme(s) under the stress 


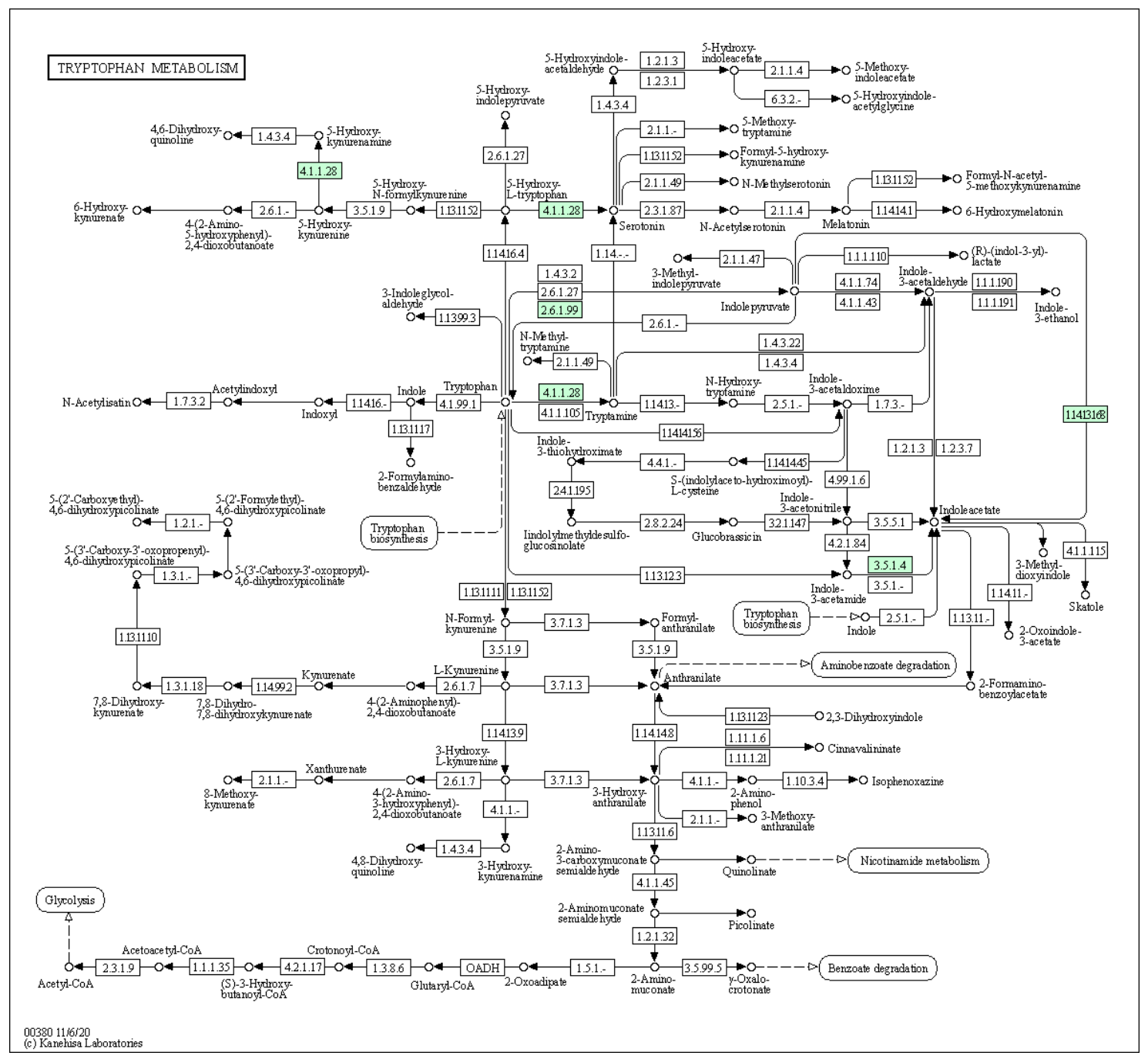

Figure A5. Metabolites in the "Tryptophan metabolism" pathway that can be enriched due to salt stress $(200 \mathrm{mM} \mathrm{NaCl})$ in leaves of Jojoba plant. Colored boxes refer to enriched enzyme(s) under the stress

PLANT HORMONE SIGNAL TRANSDUC TION

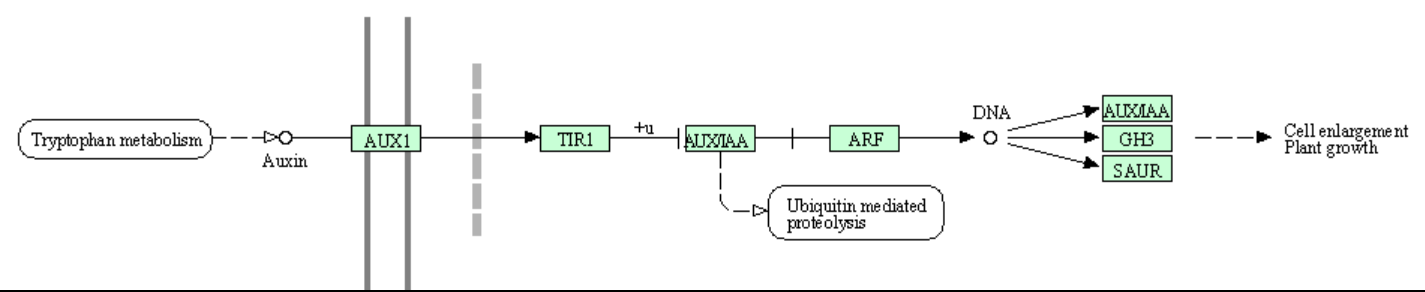

Figure A6. Metabolites in the "Plant hormone signal transduction" pathway that can be enriched due to salt stress (200 $\mathrm{mM} \mathrm{NaCl}$ ) in leaves of Jojoba plant. Colored boxes refer to enriched enzyme(s) under the stress 


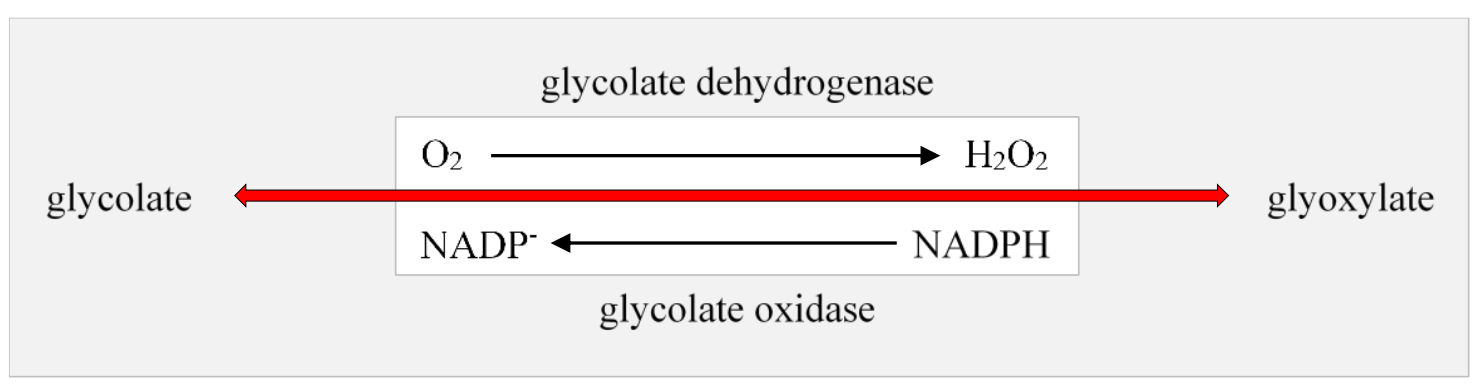

Figure A7. Glycolate oxidation can be catalyzed either by a glycolate dehydrogenase (top) or a glycolate oxidase (bottom) (Kern et al., 2020)

Table A1. Mean values of chlorophyll-a, chlorophyll-b and carotenoids ( $\mathrm{mg} / \mathrm{g} F W)$ in leaves of non-salinized $(C)$ and salinized $(T)$ Jojoba plants at three NaCl concentrations (50, 100, and $200 \mathrm{mM}$ ) increased incrementally with five-day intervals (days 25, 30 and 35, respectively). Means were calculated for three replicates. Statistical analysis was done with $P$ value of $<0.05 . N S=$ non-significant , Sig. = significant

\begin{tabular}{|c|c|c|c|c|c|c|c|}
\hline & Sample & $\mathbf{N}$ & Mean & SD & $\mathbf{t}$ & P-value & Sig. \\
\hline \multirow{6}{*}{ Chlorophyll-a } & $\mathrm{C} 25$ & 3 & 2.56 & 0.17 & \multirow{2}{*}{1.123} & \multirow{2}{*}{0.324} & \multirow{2}{*}{ NS } \\
\hline & $\mathrm{T} 25$ & 3 & 2.42 & 0.12 & & & \\
\hline & $\mathrm{C} 30$ & 3 & 1.95 & 0.21 & \multirow{2}{*}{1.092} & \multirow{2}{*}{0.336} & \multirow{2}{*}{ NS } \\
\hline & $\mathrm{T} 30$ & 3 & 1.70 & 0.35 & & & \\
\hline & $\mathrm{C} 35$ & 3 & 1.36 & 0.26 & \multirow{2}{*}{0.873} & \multirow{2}{*}{0.432} & \multirow{2}{*}{ NS } \\
\hline & T35 & 3 & 1.71 & 0.64 & & & \\
\hline \multirow{6}{*}{ Chlorophyll-b } & $\mathrm{C} 25$ & 3 & 3.14 & 0.31 & \multirow{2}{*}{0.412} & \multirow{2}{*}{0.701} & \multirow{2}{*}{ NS } \\
\hline & $\mathrm{T} 25$ & 3 & 3.04 & 0.05 & & & \\
\hline & $\mathrm{C} 30$ & 3 & 5.05 & 0.68 & \multirow{2}{*}{-1.800} & \multirow{2}{*}{0.146} & \multirow{2}{*}{ NS } \\
\hline & $\mathrm{T} 30$ & 3 & 5.85 & 0.35 & & & \\
\hline & $\mathrm{C} 35$ & 3 & 5.48 & 0.21 & \multirow{2}{*}{2.814} & \multirow{2}{*}{0.048} & \multirow{2}{*}{ Sig. } \\
\hline & T35 & 3 & 4.76 & 0.39 & & & \\
\hline \multirow{6}{*}{ Carotenoids } & $\mathrm{C} 25$ & 3 & 8.67 & 0.82 & \multirow{2}{*}{0.658} & \multirow{2}{*}{0.546} & \multirow{2}{*}{ NS } \\
\hline & $\mathrm{T} 25$ & 3 & 7.96 & 0.48 & & & \\
\hline & $\mathrm{C} 30$ & 3 & 12.92 & 0.49 & \multirow{2}{*}{4.211} & \multirow{2}{*}{0.014} & \multirow{2}{*}{ Sig. } \\
\hline & T30 & 3 & 14.78 & 0.59 & & & \\
\hline & $\mathrm{C} 35$ & 3 & 13.57 & 1.67 & \multirow{2}{*}{3.410} & \multirow{2}{*}{0.027} & \multirow{2}{*}{ Sig. } \\
\hline & $\mathrm{T} 35$ & 3 & 10.18 & 0.39 & & & \\
\hline
\end{tabular}


Table A2. Mean values of hydrogen peroxide $\left(\mu \mathrm{mol}^{-1} \mathrm{~cm}^{-1}\right)$, catalase (CAT) activity $(U / \mathrm{g}$ $F W)$ and ascorbate peroxidase $(A P X)$ activity $(U / g F W)$ in leaves of non-salinized $(C)$ and salinized (T) Jojoba plants at three $\mathrm{NaCl}$ concentrations (50, 100, and $200 \mathrm{mM}$ ) increased incrementally with five-day intervals (days 25, 30 and 35, respectively). Means were calculated for three replicates. Statistical analysis was done with $P$ value of $<0.05$. $N S=$ non-significant, Sig. $=$ significant

\begin{tabular}{|c|c|c|c|c|c|c|c|}
\hline & Sample/Concentration & $\mathbf{N}$ & Mean & SD & $\mathbf{t}$ & P-value & Sig. \\
\hline \multirow{6}{*}{$\mathrm{H}_{2} \mathrm{O}_{2}$ Conc. } & $\mathrm{C} 25$ & 3 & 13.12 & 0.56 & \multirow{2}{*}{8.845} & \multirow{2}{*}{0.001} & \multirow{2}{*}{ Sig. } \\
\hline & T25 & 3 & 9.32 & 0.49 & & & \\
\hline & C30 & 3 & 11.71 & 0.35 & \multirow{2}{*}{5.426} & \multirow{2}{*}{0.006} & \multirow{2}{*}{ Sig. } \\
\hline & T30 & 3 & 8.99 & 0.80 & & & \\
\hline & C35 & 3 & 12.34 & 0.31 & \multirow{2}{*}{-6.280} & \multirow{2}{*}{0.003} & \multirow{2}{*}{ Sig. } \\
\hline & T35 & 3 & 15.22 & 0.73 & & & \\
\hline \multirow{6}{*}{$\begin{array}{l}\text { CAT Enzyme } \\
\text { activity }\end{array}$} & C25 & 3 & 13.11 & 2.78 & \multirow{2}{*}{-8.580} & \multirow{2}{*}{0.001} & \multirow{2}{*}{ Sig. } \\
\hline & $\mathrm{T} 25$ & 3 & 27.16 & 0.56 & & & \\
\hline & $\mathrm{C} 30$ & 3 & 41.88 & 1.46 & \multirow{2}{*}{-23.538} & \multirow{2}{*}{0.000} & \multirow{2}{*}{ Sig. } \\
\hline & T30 & 3 & 168.53 & 9.20 & & & \\
\hline & C35 & 3 & 35.35 & 6.34 & \multirow{2}{*}{-2.340} & \multirow{2}{*}{0.079} & \multirow{2}{*}{ NS } \\
\hline & $\mathrm{T} 35$ & 3 & 45.93 & 4.59 & & & \\
\hline \multirow{6}{*}{$\begin{array}{l}\text { APX Enzyme } \\
\text { activity }\end{array}$} & $\mathrm{C} 25$ & 3 & 4.58 & 0.95 & \multirow{2}{*}{-0.247} & \multirow{2}{*}{0.817} & \multirow{2}{*}{ NS } \\
\hline & $\mathrm{T} 25$ & 3 & 5.98 & 9.80 & & & \\
\hline & C30 & 3 & 7.06 & 1.81 & \multirow{2}{*}{-3.622} & \multirow{2}{*}{0.022} & \multirow{2}{*}{ Sig. } \\
\hline & T30 & 3 & 11.23 & 0.83 & & & \\
\hline & C35 & 3 & 14.84 & 2.34 & \multirow{2}{*}{-0.507} & \multirow{2}{*}{0.639} & \multirow{2}{*}{ NS } \\
\hline & T200 & 3 & 15.63 & 1.41 & & & \\
\hline
\end{tabular}

\section{ELECTRONIC APPENDIX}

This paper has an electronic appendix. 